Ocean Sci. Discuss., https://doi.org/10.5194/os-2017-104

Manuscript under review for journal Ocean Sci.

Discussion started: 2 January 2018

(c) Author(s) 2018. CC BY 4.0 License.

Ocean Science

Discussions

(c) (1)

\title{
Seasonal and interannual (ENSO) climate variabilities and trends in \\ the South China Sea over the last three decades
}

\author{
Violaine Piton (1, 2) and Thierry Delcroix (1) \\ (1) LEGOS, CNES, CNRS, IRD, UPS, University of Toulouse, France \\ (2) University of Sciences and Technology of Hanoi, Hanoi, Vietnam
}

Corresponding author: thierry.delcroix@legos.obs-mip.fr 
Ocean Sci. Discuss., https://doi.org/10.5194/os-2017-104

Manuscript under review for journal Ocean Sci.

Discussion started: 2 January 2018

(c) Author(s) 2018. CC BY 4.0 License.

\section{Abstract}

2 We present a short overview of the long-term mean and variability of five Essential Climate

3 Variables observed in the South China Sea over the last 3 decades, including sea surface

4 temperature (SST), sea level anomaly (SLA), precipitation (P), surface wind and water

5 discharge (WD) from the Mekong and Red Rivers. At the seasonal time scale, SST and SLAs

6 increase in the summer (up to $4.2^{\circ} \mathrm{C}$ and $14 \mathrm{~cm}$, respectively), and $\mathrm{P}$ increases in the north.

7 The summer zonal and meridional winds reverse and intensify (mostly over the ocean), and

8 the WD shows positive anomalies. At the interannual time scale, each variable appears to be

9 correlated with El Niño Southern Oscillation (ENSO) indices. Eastern Pacific El Niño events

10 produce basin-wide SST warming (up to $1.4^{\circ} \mathrm{C}$ ) with a 6-month lag. The SLAs fall basin-wide

11 (by up to $9 \mathrm{~cm}$ ) during an El Niño event, with a 3-month lag. The zonal and meridional winds strengthen (up to $4 \mathrm{~m} / \mathrm{s}$ ) in the north (weaken in the south) during all types of El Niño events, with a 3-5-month lag. A rainfall deficit of approximately $30 \%$ of the mean occurs during all types of El Niño phases. The Mekong River WD is reduced by $1 / 3$ of the mean 7-8 months after all types of El Niño events. We also show increasing trends of SST as high as $0.24^{\circ} \mathrm{C} /$ decade and SLAs by $41 \mathrm{~mm} /$ decade. Increasing trends are observed for zonal wind, which is possibly linked to the phase of the Pacific Decadal Oscillation, and decreasing trends are observed for P in the north and both WD stations that were analyzed. The likely driving mechanisms and some of the relationships between all observed anomalies are discussed.

Keywords: ENSO, trends, climate variability, essential climate variable, South China Sea, seasonal variability 


\section{Introduction}

The South China Seas (hereafter, SCS) is the largest marginal sea in Southeast Asia and covers an area of 3.8 million $\mathrm{km}^{2}$ from approximately $0-23^{\circ} \mathrm{N}$ and $99^{\circ} \mathrm{E}-121^{\circ} \mathrm{E}$ (Fig. 1). This semi-closed basin is surrounded by South China, the Indochina Peninsula, Borneo and the Philippines. It is open to the East China Sea through the Taiwan Strait, to the Pacific through the Luzon Strait and to the Indian Ocean through the Malacca Strait and other narrow straits. The SCS is the second busiest maritime route in the world; its topography is rather complex with an average depth of $2000 \mathrm{~m}$ and maximum depths reaching $5000 \mathrm{~m}$ in the northeast. There are wide and shallow continental shelves in the northwest and southwest of the SCS and numerous islands such as Hainan, Paracel and Spratly.

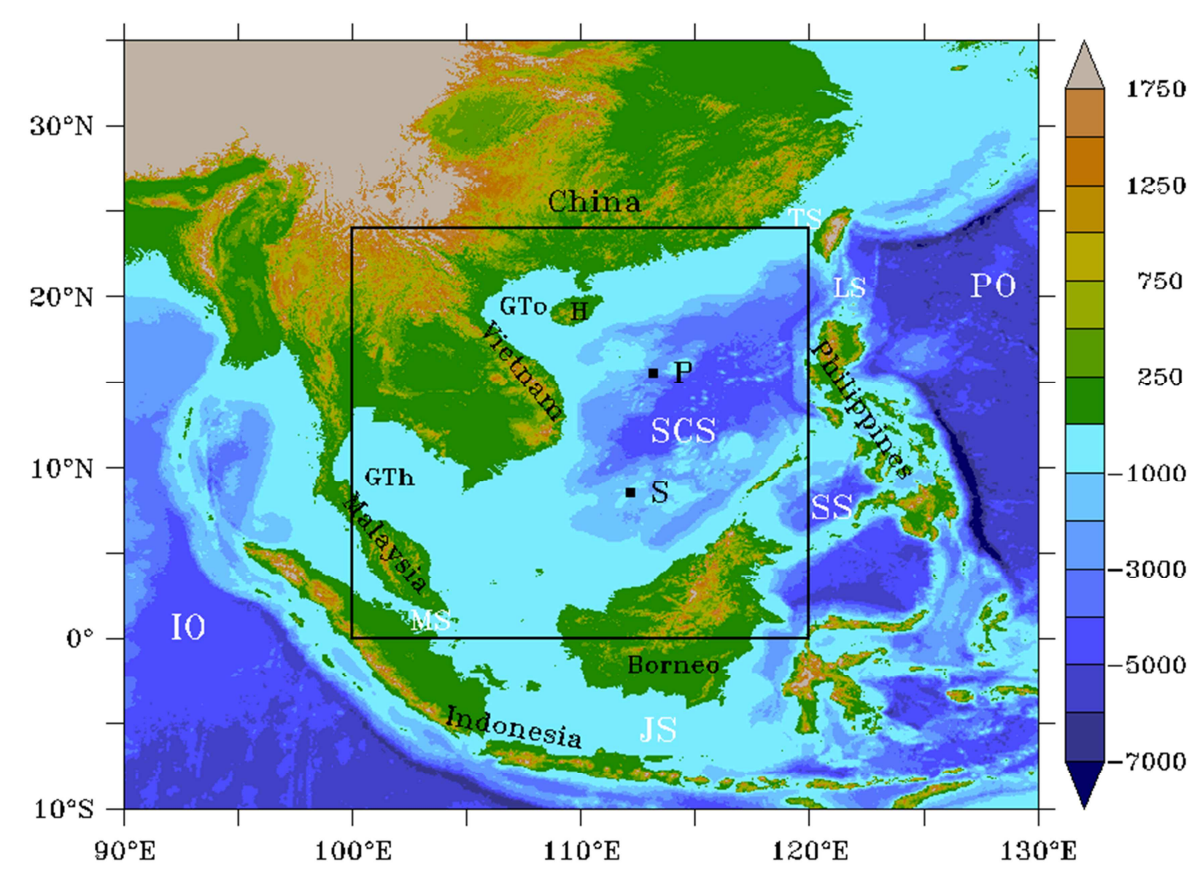

Figure 1. Bathymetry below sea level and topography above sea level (in m) of the South China Sea region. Our research domain is enclosed with a black rectangle. The acronyms denote, GTh Gulf of Thailand, GTo Gulf of Tonkin, $H$ Hainan island, IO Indian Ocean, JS Java Sea, MS Malacca Strait, LS Luzon Strait, TS Taiwan Strait, $P$ Paracel Islands, $P O$ Pacific Ocean, 
Ocean Sci. Discuss., https://doi.org/10.5194/os-2017-104

Manuscript under review for journal Ocean Sci.

Discussion started: 2 January 2018

S Spratly Islands, SCS South China Sea, and SS Sulu Sea. The bathymetry intervals are from 0 to $1000 \mathrm{~m}$, and the topography intervals are from 0 to $250 \mathrm{~m}$. tropical and a subtropical climate, by the four adjacent monsoon subsystems, as well as by the inflow from and the outflow to the surrounding oceans (see the reviews by Wang et al., 2009, and Qu et al., 2009). At the annual time scale, the climate is mainly determined by two alternative monsoon cycles, a southwest monsoon that brings wet and warm weather over the area in the boreal summer (hereafter, all seasons will refer to the northern hemisphere seasons) and a northeast monsoon that brings cold and dry conditions in the winter (Wyrtki, 1961; Wang and LinHo, 2002; Nguyen et al., 2014). Moreover, at the interannual time scale, the SCS region is further influenced by the El Niño-Southern Oscillation (ENSO) phenomena. Several studies have been conducted on the interannual (ENSO) variability of the SCS in terms of sea surface temperature (Huynh et al., 2016; Liu et al., 2014; Tan et al., 2016; Yang et al., 2015; Wang et al., 2006), sea level (Peng et al., 2013; Rong et al., 2007), surface winds (Huynh et al., 2016), precipitation (Juneng and Tangang 2005; Nguyen et al., 2014; Räsänen and Kummu, 2013; Räsänen et al., 2016), cyclone frequency occurrences (Camargo and Sobel, 2005; Wu et al., 2005), and river runoff (Räsänen and Kummu, 2013; Xue et al., 2011). Some of the aforementioned studies have focused further on the trends in the analyzed variables, especially to estimate the potential impacts of global warming or decadal variability (e.g., Peng et al., 2013; Xue et al., 2011).

As a complement to the large and growing body of regional climate-related publications stemming from different authors, journal articles, datasets, and analyses of specific time periods and time scales, the goal of the present study is to make an original contribution to the literature by attempting to provide a concise and integrated analysis of five key oceanic, atmospheric and terrestrial variables. To our knowledge, this study is actually the first co-analysis of regional (SCS) oceanographic variables conducted over a 
multi-decadal time frame made possible by the presence of long-term data products. For this co-analysis, our approach is based on a coherent methodology, using the same technique for each key variable, comparing each variable with the same ENSO indices, computing trends over the same period, and using either new or longer datasets than the ones currently found in the literature. Furthermore, this study provides an analysis of altimeter-derived Mekong and Red Rivers discharge, which has not been previously documented, as well as in situ P changes in near-coastal stations of Vietnam. The five key variables studied here are sea surface temperature, sea level anomalies, surface winds, precipitation and river discharge, all of which are considered an Essential Climate Variable (ECV) in the frame of the Global Climate Observing Systems (GCOS, 2016). (In total, 50 variables covering three domains, atmospheric, oceanic and terrestrial, are referenced as ECVs).

The five ECV datasets and the common data analysis methods based on temporal filtering and EOF analysis are detailed in section 2. Their long-term means and standard deviations (denoting the overall variability) are described in section 3 to set the context. Then, their seasonal and interannual (ENSO) variabilities are analyzed in sections 4 and 5, respectively. The long-term trends are finally documented in section 6. Aiming to be a short overview paper, the knowledge gained from our study is compared to a variety of previous results in all sections. A conclusion and discussion section is given in section 7.

\section{Data and Methods}

Five ECVs are investigated: sea surface temperature (SST), sea level anomaly (SLA), surface wind (SW), precipitation (P) and water discharge (WD). Among the multiple available databases, all of the products that are described next have been selected based on a compromise between several criteria: the dataset is as long as possible, grid resolution must be as fine as possible, confidence, robustness and/or 'clear' documentation of the product (partly based on a literature review). 
Ocean Sci. Discuss., https://doi.org/10.5194/os-2017-104

Manuscript under review for journal Ocean Sci.

Discussion started: 2 January 2018 (daily OISST) version 2.0 developed by the National Oceanic and Atmospheric Administration (NOAA; Reynolds et al., 2007; Reynolds 2009). (Note that all websites we used to get the data are listed in the Acknowledgements section below). We extracted the merged and gridded SST data covering the SCS from $0-24^{\circ} \mathrm{N}$ to $100-120^{\circ} \mathrm{E}$ and spanning from $01 / 1982$ to $12 / 2015$ (34 years).

SLA. We used the multi-mission gridded sea level anomaly (MSLA) product produced by AVISO+ (Archiving, Validation and Interpretation of Satellite Oceanographic Data) that was based on TOPEX/Poseidon, Jason 1, ERS-1 and ERS-2 data. This product provides SLAs relative to a 20-year mean from 1993 to 2012 . This weekly data set is averaged to produce the monthly mean data set in the present work and covers the same area as the SST data from $01 / 1993$ to $12 / 2015$ (23 years) with a resolution of $0.25^{\circ} \times 0.25^{\circ}$. The mean dynamic topography (called the CNES-CLS13 MDT) was also obtained from AVISO+ and gives the surface height above geoid over the period 1993-2012 (Rio et al., 2014). This product is based on two years of GOCE (Gravity Field and Steady-State Ocean Circulation Explorer) data, seven years of GRACE (Gravity Recovery and Climate Experiment) data and 20 years of altimetry and in situ data.

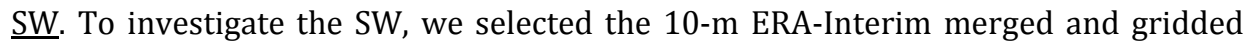
wind data developed by the European Centre for Medium-Range Weather Forecasts (ECMWF; Dee et al., 2011). The data are available monthly on a $0.75^{\circ} \times 0.75^{\circ}$ spatial grid covering the entire region for the period $01 / 1979$ to $12 / 2015$ (37 years). same resolution and time coverage as previously noted. To further the study of precipitation, we selected to investigate the land rainfall measurements provided by Vietnam's HydroMeteorological Service. Among the 172 rainfall stations available, only 17 are considered in 
Ocean Sci. Discuss., https://doi.org/10.5194/os-2017-104

Manuscript under review for journal Ocean Sci.

Discussion started: 2 January 2018

(c) Author(s) 2018. CC BY 4.0 License.

125

126

127

128

129

130

131

132

133

134

135

cover at least 28 consecutive years, b) the dataset should not contain any missing data, c) the spatial distribution must be homogeneous across Vietnam, and d) at least one station must be located in each of the eight climatic zones of Vietnam described in Gobin (2016). The locations and primary characteristics of the 17 selected rainfall stations are shown in Table 1. The correlation coefficients (R) between the in situ and ERA-Interim reanalysis time series sampled near each station were high, and the values were similar for both seasonal and interannual time scales $(0.5<\mathrm{R}<0.98)$. However, the ERA-Interim product tended to underestimate the mean observed rainfall by approximately 16\% (comparison made between the 17 selected stations). Only 3 times series representing the northern (Lục Yên), central (Đà Nẵng) and southern (Mỹ Tho) parts of Vietnam are presented in the following section.

\begin{tabular}{|c|c|c|c|c|}
\hline Position & Name & Mean & $\begin{array}{l}\text { Standard } \\
\text { Deviation }\end{array}$ & Linear Trend \\
\hline $21^{\circ} .22^{\prime} \mathrm{N}, 103^{\circ} .00^{\prime} \mathrm{E}$ & Điện Biên & 4.31 & 4.37 & $-2.4 \times 10^{-1}$ \\
\hline $22^{\circ} .06^{\prime} \mathrm{N}, 104^{\circ} .43^{\prime} \mathrm{E}$ & Lục Yên & 8.18 & 6.05 & $-2.64 \times 10^{-1}$ \\
\hline $21^{\circ} .10^{\prime} \mathrm{N}, 105^{\circ} .03^{\prime} \mathrm{E}$ & Minh Đài & 4.93 & 4.86 & $-7.8 \times 10^{-1}$ \\
\hline $22^{\circ} .50^{\prime} \mathrm{N}, 106^{\circ} .31^{\prime} \mathrm{E}$ & Trùng Khánh & 4.90 & 4.38 & $-1.53 \times 10^{-1}$ \\
\hline $21^{\circ} .01^{\prime} \mathrm{N}, 107^{\circ} .21^{\prime} \mathrm{E}$ & Cửa Ông & 4.97 & 5.73 & $-4.10 \times 10^{-2}$ \\
\hline $20^{\circ} .39^{\prime} \mathrm{N}, 106^{\circ} .03^{\prime} \mathrm{E}$ & Hưng Yên & 3.94 & 3.80 & $7.42 \times 10^{-4}$ \\
\hline $19^{\circ} .10^{\prime} \mathrm{N}, 105^{\circ} .38^{\prime} \mathrm{E}$ & Quỳnh Lưu & 4.37 & 4.49 & $-7.2 \times 10^{-2}$ \\
\hline $18^{\circ} .05^{\prime} \mathrm{N}, 106^{\circ} .17^{\prime} \mathrm{E}$ & Kỳ Anh & 5.68 & 6.32 & $-4.71 \times 10^{-1}$ \\
\hline $16^{\circ} .80^{\prime} \mathrm{N}, 106^{\circ} .60^{\prime} \mathrm{E}$ & Đông Hà & 10.48 & 11.55 & $-5.20 \times 10^{-1}$ \\
\hline $16^{\circ} .02^{\prime} \mathrm{N}, 108^{\circ} .12^{\prime} \mathrm{E}$ & Đà Nẵng & 14.42 & 15.00 & 1.48 \\
\hline $14^{\circ} .46^{\prime} \mathrm{N}, 108^{\circ} .44^{\prime} \mathrm{E}$ & Ba Tơ & 7.12 & 9.36 & $7.42 \times 10^{-1}$ \\
\hline $13^{\circ} .03^{\prime} \mathrm{N}, 108^{\circ} .59^{\prime} \mathrm{E}$ & Sơn Hoà & 4.93 & 6.76 & $1.57 \times 10^{-1}$ \\
\hline $11^{\circ} .45^{\prime} \mathrm{N}, 108^{\circ} .23^{\prime} \mathrm{E}$ & Liên Khương & 7.98 & 6.22 & $8.12 \times 10^{-1}$ \\
\hline $11^{\circ} .50^{\prime} \mathrm{N}, 106^{\circ} .59^{\prime} \mathrm{E}$ & Phước Long & 6.78 & 5.78 & $3.53 \times 10^{-1}$ \\
\hline $10^{\circ} .47^{\prime} \mathrm{N}, 105^{\circ} .56^{\prime} \mathrm{E}$ & Mộc Hoá & 4.05 & 4.14 & $-1.08 \times 10^{-1}$ \\
\hline $10^{\circ} .21^{\prime} \mathrm{N}, 106^{\circ} .24^{\prime} \mathrm{E}$ & Mỹ Tho & 8.54 & 6.78 & $6.73 \times 10^{-1}$ \\
\hline $9^{\circ} .17^{\prime} \mathrm{N}, 105^{\circ} .43^{\prime} \mathrm{E}$ & Bạc Liêu & 5.85 & 5.37 & $6.45 \times 10^{-4}$ \\
\hline ST $\left(21^{\circ} .20^{\prime} \mathrm{N}, 105^{\circ} .50^{\prime} \mathrm{E}\right)$ & Sơn Tây & 3540 & 2960 & -520 \\
\hline
\end{tabular}




\begin{tabular}{|c|c|c|c|c|}
\hline CCV Satellites & Chroy Chang Var & 12400 & 8280 & -1220 \\
\hline $\begin{array}{c}\text { CCV in situ }\left(12^{\circ} .50^{\prime} \mathrm{N},\right. \\
\left.105^{\circ} .65^{\prime} \mathrm{E}\right)\end{array}$ & Chroy Chang Var & 11600 & 10700 & -1340 \\
\hline
\end{tabular}

Table 1. Means, standard deviations and trends from the 17 selected inland rainfall stations coordinates. The values were computed over the 1979-2006 period for the rainfall stations, over the 1960-2010 period for the ST gauge station, over the 1960-2002 period for the in situ measurements at CCV and over the 1996-2015 period for CCV from satellite measurements. Mekong River, which are represented by the Son Tay (ST) station and the Chroy Chang Var (CCV) station (located in Cambodia), respectively (see Fig 3e for locations). The latter station was selected to avoid the tidal effects on the water level in the Mekong Delta. In situ data are available at the ST and CCV stations, and water discharges were further computed from altimetry at the CCV station. Radar altimetry discharges were obtained applying a rating curve that related the water stage and discharge to the altimetry-based water level (e.g., Kouraev et al., 2004; Frappart et al., 2015). The time-series of altimetry-based water levels was obtained using the Multi-Mission Altimetry Processing Software (MAPS - Frappart et al., 2015) to process the along-track altimetry data from ERS-2 (1996-2003), ENVISAT (20022010 on the nominal orbit) and Jason-2 (2008-2016 on the nominal orbit). The data, made available by the Centre de Topographie des Océans et de l'Hydrosphère (CTOH), came from the Geophysical Data Records (GDRs) D for Jason-2 and v2.1 for ENVISAT and from the reprocessing of the ERS-2 radar echoes performed at $\mathrm{CTOH}$ to ensure the continuity with ENVISAT for land studies (Frappart et al., 2016). In situ data at the ST station are provided by Vietnam's Hydro-Meteorological Service and cover the period 1960 to 2010. The data 
Ocean Sci. Discuss., https://doi.org/10.5194/os-2017-104

Manuscript under review for journal Ocean Sci.

Discussion started: 2 January 2018

2002. The mean annual discharges from the gauge stations at the CCV station were compared to the satellite data over the common period of measurements, 1996 to 2002. It appeared that the annual means of the in situ measurements were adequately represented by the satellite measurements since the slope of the regression line (between in situ and satellite measurements) is close to one.

Climate indices. The interannual signal that was extracted from the original time series (see the following paragraph) was compared to several well-known climate indices to search for possible relationships with the atmospheric El Niño Southern Oscillation (ENSO) Index (SOI) (Allan et al., 1996), the oceanic ENSO indices through the SST Niño3.4 $\left(5^{\circ} \mathrm{S}-5^{\circ} \mathrm{N}\right.$, $\left.170^{\circ} \mathrm{W}-120^{\circ} \mathrm{W}\right)$, SST Niño4 $\left(5^{\circ} \mathrm{S}-5^{\circ} \mathrm{N}, 160^{\circ} \mathrm{E}-150^{\circ} \mathrm{E}\right)$ and SST Niño1+2 $\left(10^{\circ} \mathrm{S}-0^{\circ}, 90^{\circ} \mathrm{W}-80^{\circ} \mathrm{W}\right)$ indices (Trenberth and Stepaniak, 2001 Rayner et al., 2003), and the El Niño Modoki index (EMI) (Ashok et al., 2007). The SST Niño1+2 index is preferentially used to characterize Eastern Pacific (EP) ENSO events. The SST Niño4 index is preferentially used to characterize all types of El Niño events, but the authors could have chosen to use either the SOI or the SST Niño3.4, as the phases of these three indices are almost equally sensitive to El Niño events (Hanley et al., 2003). Data processing. The climatological means, standard deviations (STDs), seasonal and interannual variations were quantified for each ECV. The climatological means and STDs were calculated over the entire length of each dataset (ranging from 23 to 37 years). The seasonal variations were estimated by constructing a typical year for each ECV. This method consists of computing the mean of each month $(J, F, \ldots, D)$ of the year over the multiyear series. The interannual variations were estimated by subtracting the typical year from the original series, which removes the mean seasonal cycle and filtering the remaining signal with a 13-month low-pass Hanning filter. The filter passes almost no signals at periods less than or equal to six months, filtering out the intraseasonal variability, and shortens each 
analyses were then performed on the typical years and low-pass filtered time series, which were first detrended. EOF analyses allow us to extract the main spatial modes of variability and determine how they can change over time (e.g., Hannachi et al., 2007). Only statistically consistent EOFs, based on North et al. (1982), are shown here, and all of the values presented below are significant at the $90 \%$ confidence level (except for the P and WD stations, as we did not perform EOFs on these series). Although statistically significant, some EOF modes equal to or greater than two are not presented below because we did not find any simple physical mechanisms possibly accounting for their related temporal and spatial functions.

The long-term trends were computed by least-square fitting a straight line to the monthly time series over the entire length of each dataset. The long-term trends over a common period of measurement of 27 years (1979-2006) are also calculated and presented when available (for P and SW from Era-Interim, P in situ and WD at ST).

\section{ECV means and standard deviations}

The mean and standard deviation are presented for each oceanic and atmospheric variable in Figures 2 and 3, respectively, and the atmospheric variables are available over both the ocean and continent.

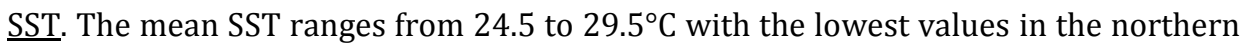
part of the SCS basin and along the coasts of Vietnam (Fig. 2a), in agreement with Tuen (1994), Chu et al. (1997) and Qu (2001) to name a few. Liu et al. (2004) also emphasized a (relatively) cold tongue of water as the result of the advection of cold waters from the north via the western part of the cyclonic gyre that develops in the winter in the area. The standard deviation (Fig. $2 \mathrm{~b}$ ) ranges from 0.5 to $3.5^{\circ} \mathrm{C}$ with a high variability in the northern part of the basin. On both the mean and standard deviation maps, the northeast-southwest oriented isotherms are observed to have low temperatures and high standard deviations in the north-northwest (see also Chu et al., 1997, and Qu, 2001). The lowest SSTs are mainly 
Ocean Sci. Discuss., https://doi.org/10.5194/os-2017-104

Manuscript under review for journal Ocean Sci.

Discussion started: 2 January 2018

(c) Author(s) 2018. CC BY 4.0 License.

212 caused by the northeast winds that blow in the winter, which first cool the seawater by

213 bringing cold and dry air and second generate a southwest-ward coastal current, which, in 214 return, brings cold coastal waters from the East China Sea into the SCS (Fang et al., 2006).

a) Mean SST

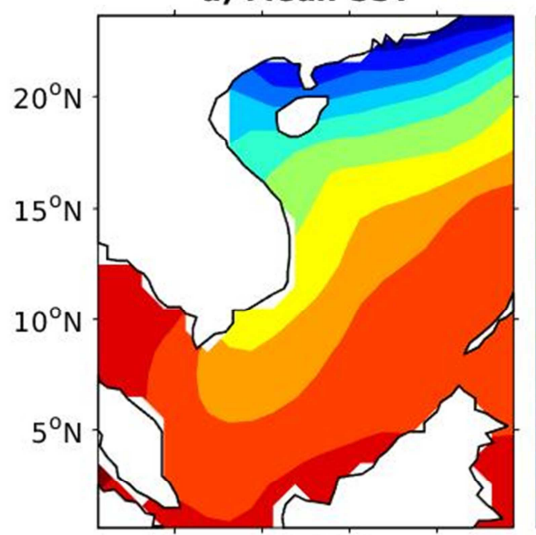

c) MDT

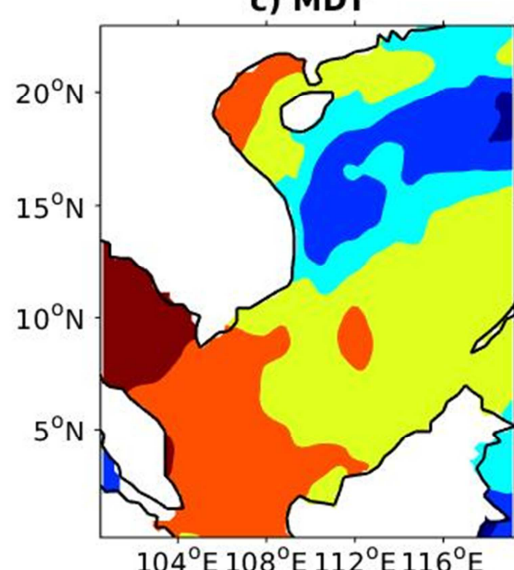

b) Std SST

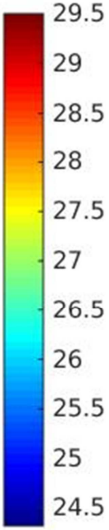

4.5

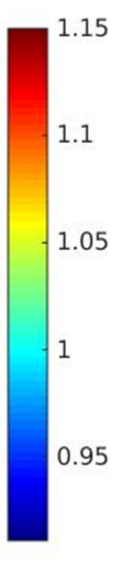

d) Std SL
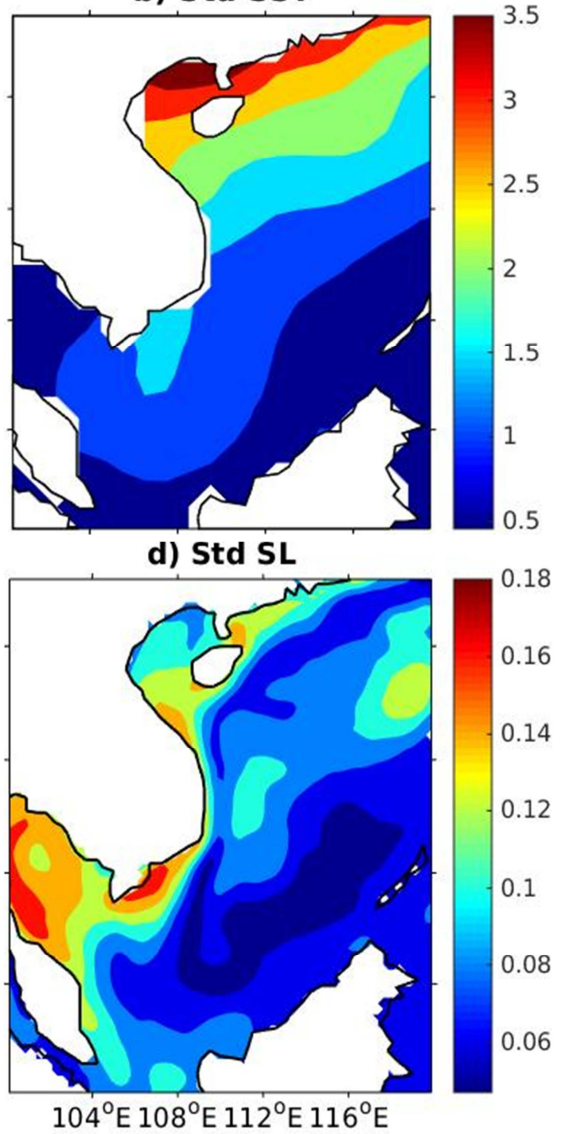

217 Figure 2. Mean and standard deviation of SST (a and b, respectively) in ${ }^{\circ} \mathrm{C}$, and mean

dynamical topography (MDT) and standard deviation of SLA (c and d, respectively) in m. The

values were computed over 1982-2015 for SST, and 1993-2012 for MDT. The color codes

differ between the figures.

SLA. The map of the mean dynamic topography (MDT) shows spatial inhomogeneity throughout the basin, featuring the mean surface geostrophic circulation (Fig. 2c). The western and the southwestern parts of the SCS are characterized by the highest rates of 
Ocean Sci. Discuss., https://doi.org/10.5194/os-2017-104

Manuscript under review for journal Ocean Sci.

Discussion started: 2 January 2018

(c) Author(s) 2018. CC BY 4.0 License.

MDT, ranging from 1.05 to $1.15 \mathrm{~m}$ above the reference geoid. The lowest sea surface heights, with values ranging from 0.9 to $1 \mathrm{~m}$, stretch roughly from the southern tip of Vietnam to the Luzon Strait, with minimum values near $18^{\circ} \mathrm{N}-118^{\circ} \mathrm{E}$ and $14^{\circ} \mathrm{N}-110^{\circ} \mathrm{E}$. Zhuang et al. (2010) found similarly low sea level heights at approximately $18^{\circ} \mathrm{N}-117^{\circ} \mathrm{E}$ northwest of Luzon Island that extended southeastward to the east of Vietnam. Interestingly, the MDT resembles the mean $0 / 400$ dbar dynamic topography derived from in situ temperature profiles and mean TS curves (Qu, 2000). This similarity corroborates the existence of the cyclonic West Luzon and East Vietnam eddies, which are two major features of the mean upper circulation that are centered at the minimum values noted above. The SLA standard deviations range from 6 to $18 \mathrm{~cm}$ (Fig. 2d), which is consistent with the results from Zhuang et al. (2010). These results are comparable with previous results from TOPEX/Poseidon altimeter data and Argo-tracked ocean surface drifter measurements presented by Ho et al. (2000).

$\underline{\mathrm{SW}}$. The mean surface zonal and meridional components are stronger over the sea than over the land area, and the winds mostly blow W-SW (negative values in Fig. 3ac), particularly in the northern part of the basin where the values are as high as $8.5 \mathrm{~m} / \mathrm{s}$ (approximately 16.5 knots). A mean southward flux is observed along the south of the Vietnamese coastline. It appears that the mean surface winds and the standard deviations associated with both zonal and meridional winds strongly depend upon the orographic features (lower values above lands). The interpretation of the annual mean surface wind in a region that is highly influenced by strong seasonal wind reversals due to the monsoon cycles

245 (see section 4) does not mean very much. The standard deviation values are the lowest above land (from 0.5 to $4 \mathrm{~m} / \mathrm{s}$ ) and the highest above water (from 5 to $11 \mathrm{~m} / \mathrm{s}$ ) with cores of

247 maximum values near the southern tip of Vietnam. These values mostly reflect the seasonal

248 reversal (chiefly over the ocean) of the wind driven by the summer-winter monsoon cycles. 
a) Mean Wind U

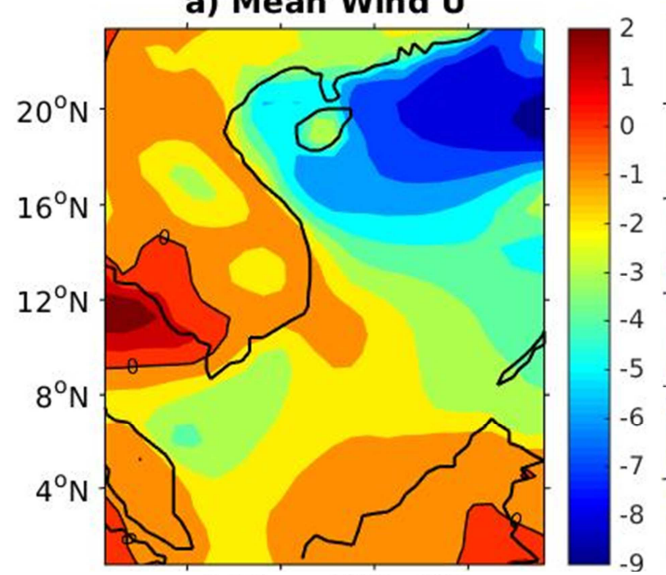

c) Mean Wind $\mathrm{V}$

250

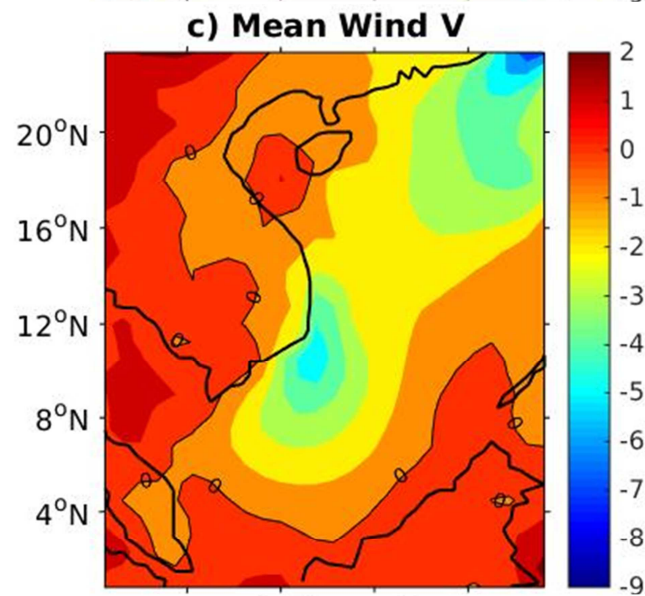

e) Mean $\mathbf{P}$

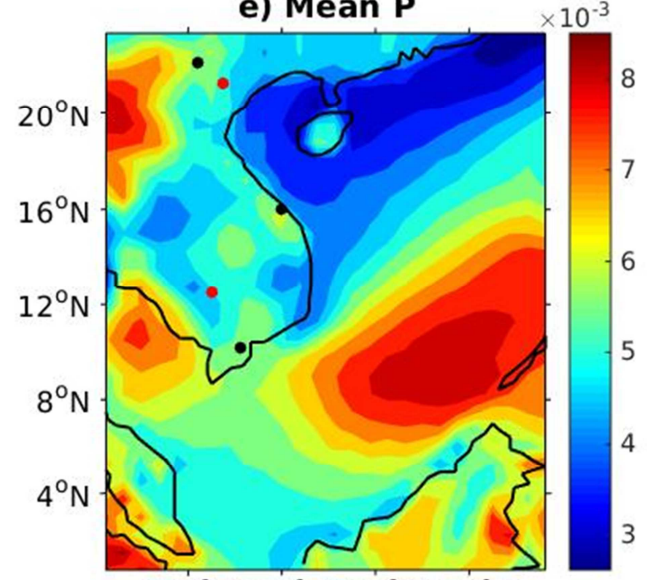

$104^{\circ} \mathrm{E} 108^{\circ} \mathrm{E} 112^{\circ} \mathrm{E} 116^{\circ} \mathrm{E}$

\section{b) Std Wind $U$}

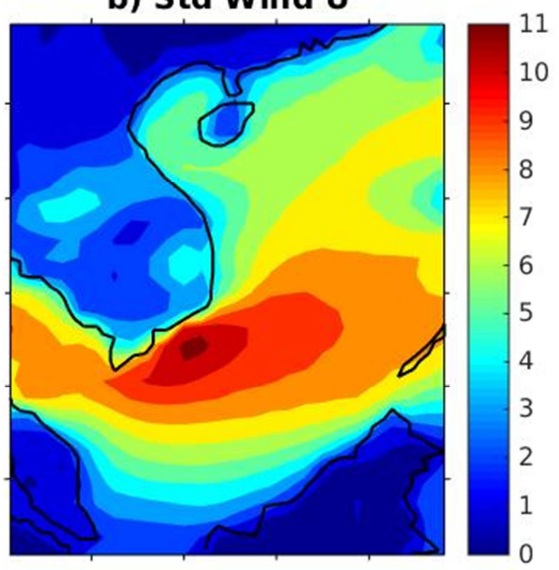

d) Std Wind V

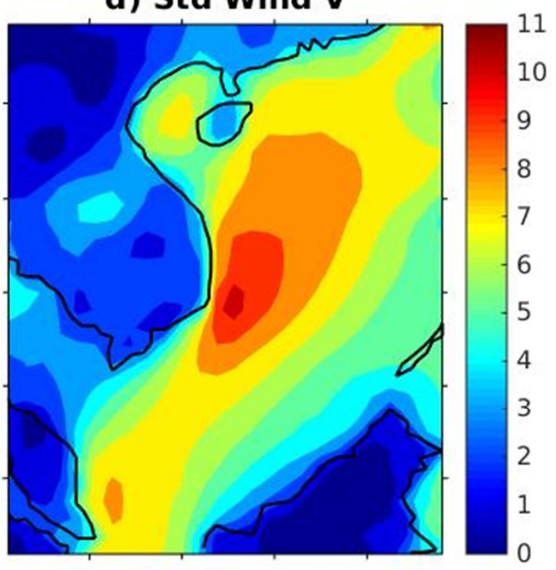

f) Std P

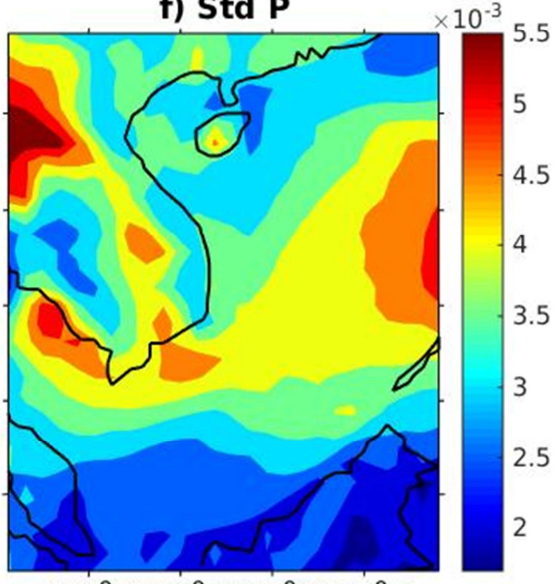

$104^{\circ} \mathrm{E} 108^{\circ} \mathrm{E} 112^{\circ} \mathrm{E} 116^{\circ} \mathrm{E}$

Figure 3. Means (a, c, e) and standard deviations (b, d, f) of the zonal and meridional surface

wind components in $\mathrm{m} / \mathrm{s}$ (noted $\mathrm{U}$ and $\mathrm{V}$, respectively) and precipitation in $\mathrm{m} / \mathrm{d}$ (noted $\mathrm{P}$ ). 
Ocean Sci. Discuss., https://doi.org/10.5194/os-2017-104

Manuscript under review for journal Ocean Sci.

Discussion started: 2 January 2018

black dots on panel (e) denote, from north to south, the location of the inland rainfall stations Lục Yên, Đà Nẵng and Mỹ Tho (see Table 1). The red dots denote the location, from north to south, of the gauge stations at the Red River ST and Mekong CCV stations. The color codes differ between the figures.

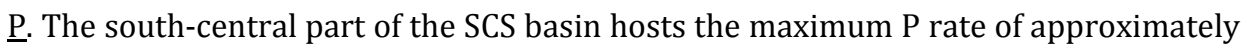
$8 \mathrm{~mm} / \mathrm{d}$. The lowest mean P rates are observed in the northern part of the basin and along the Chinese coastline (Fig. 3e). As discussed in Wang et al. (2009), the sharp P contrast between the NW and SE parts of the SCS arises from a similar SST contrast (see Fig. 2a). The standard deviation of P ranges from 1.5 to $5.5 \mathrm{~mm} / \mathrm{d}$ (Fig. 3f). The rainfalls data from in situ measurements at 17 Vietnam stations (Table 1) range from 8.2 to $14.4 \mathrm{~mm} / \mathrm{d}$ (corresponding to approximately 3 to $5.3 \mathrm{~m} / \mathrm{yr}$ ). These measurements are consistent with the results from Gobin et al. (2016) who noted that rainfall on land was measured within a range of approximately $0.65 \mathrm{~m} / \mathrm{yr}$ to more than $7.3 \mathrm{~m} / \mathrm{yr}$ for the period $1960-2009$. Here, the mean rainfall for the in situ stations that were considered is approximately $3.8 \mathrm{~m} / \mathrm{yr}$ with the highest rate in the central part (Da Nang), as found in Gobin (2016). The standard deviations range from 6.05 to $15 \mathrm{~mm} / \mathrm{d}$.

WD. At the ST Red River River station, the mean water discharge is equal to 3540 $\mathrm{m}^{3} / \mathrm{s}$ (for the period 1960 to 2010) with a standard deviation of approximately $2960 \mathrm{~m}^{3} / \mathrm{s}$, which is similar to the results from Vinh et al. (2014). At the CCV Mekong station, the mean water discharge from the gauge stations and satellites appear to be consistent (11600 and $12400 \mathrm{~m}^{3} / \mathrm{s}$, respectively).

\section{Seasonal variability}

SST. The first seasonal EOF mode on SST ( $94 \%$ of the total variance) represents an annual cycle (Fig. 4b). The spatial function is positive over the entire basin and high in the northwestern part of the basin and along the southeastern Vietnam coast (Fig. 4a). The temporal mode reaches troughs in January-December and peaks in June-July, and they 
Ocean Sci. Discuss., https://doi.org/10.5194/os-2017-104

Manuscript under review for journal Ocean Sci.

Discussion started: 2 January 2018

(c) Author(s) 2018. CC BY 4.0 License.

281

282

283

284

285

286

287

288

289

290

291

292

293

294

295

296

297

298

299

300

301

correspond to the cold northeast winter monsoon and the warm southwest summer monsoon, respectively. Thus, compared to the mean, this mode exhibits a cooling (up to $4.8^{\circ} \mathrm{C}$ ) over the entire basin in the winter and a warming (up to $4.2^{\circ} \mathrm{C}$ ) mainly in the northwest in the summer.

The second seasonal EOF mode (5\% of the total variance) represents a semi-annual cycle with peaks in April and November and troughs in January and August (Fig. 4d). The spatial function is positive over the majority of the basin and negative along the Chinese and northern Vietnamese coasts (Fig. 4c). In April, the SST can increase by as much as $1.5^{\circ} \mathrm{C}$ in the Gulf of Thailand and south of Vietnam, and can decrease by $-1.5^{\circ} \mathrm{C}$ in the Gulf of Tonkin. As noted by Huynh et al. (2016), this semi-annual variability is mostly driven by oceanic thermal advection along the northeast-southwest diagonal of the basin from two opposite directions. These authors partially associate the spatial and temporal variabilities of the second SST mode with the influence of an atmospheric anticyclone. In late March, the strong development of this anticyclone weakens the northeast monsoon (winter monsoon), which reduces the amount of clouds and rainfall over the SCS and allows more solar radiation to reach the basin. As a result, the SST increases and reaches its peak in April and provides heat and vapor for the onset of the southwest (summer) monsoon. The southwest winds trigger the development of an anticyclone in the south and a weaker cyclone in the north, leading to the advection of warm waters from the south to the northeast and cold waters from the north to the southwest. In October, the summer monsoon dissipates and allows solar radiation to warm the basin, reaching a peak in November. 
Ocean Sci. Discuss., https://doi.org/10.5194/os-2017-104

Manuscript under review for journal Ocean Sci.

Discussion started: 2 January 2018

(C) Author(s) 2018. CC BY 4.0 License.

a) EOF1 SST
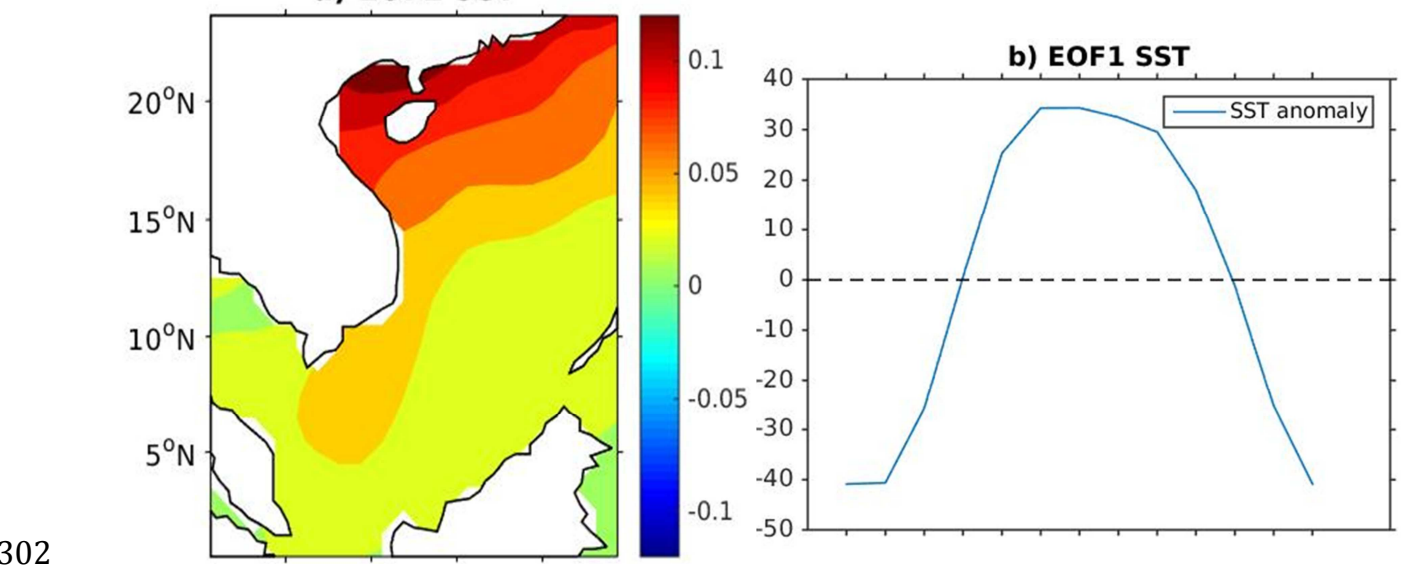

\section{c) EOF2 SST}

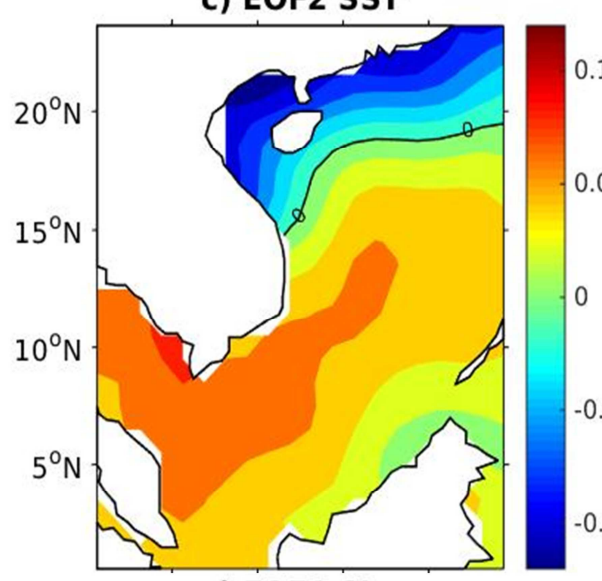

0.1

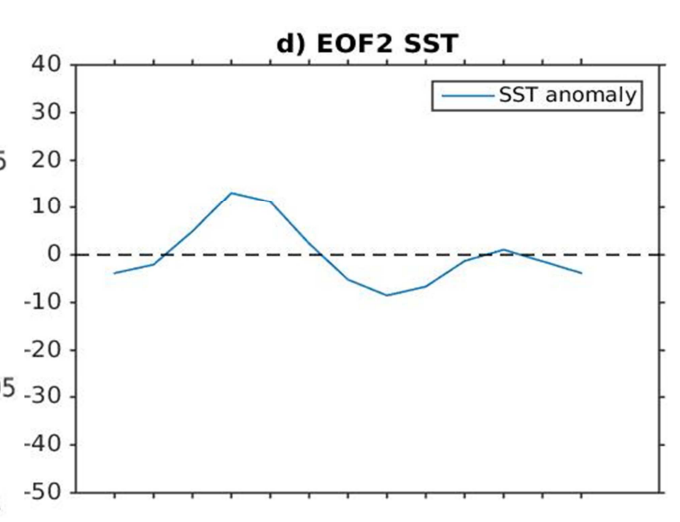

e) EOF1 SL

$-0.1$
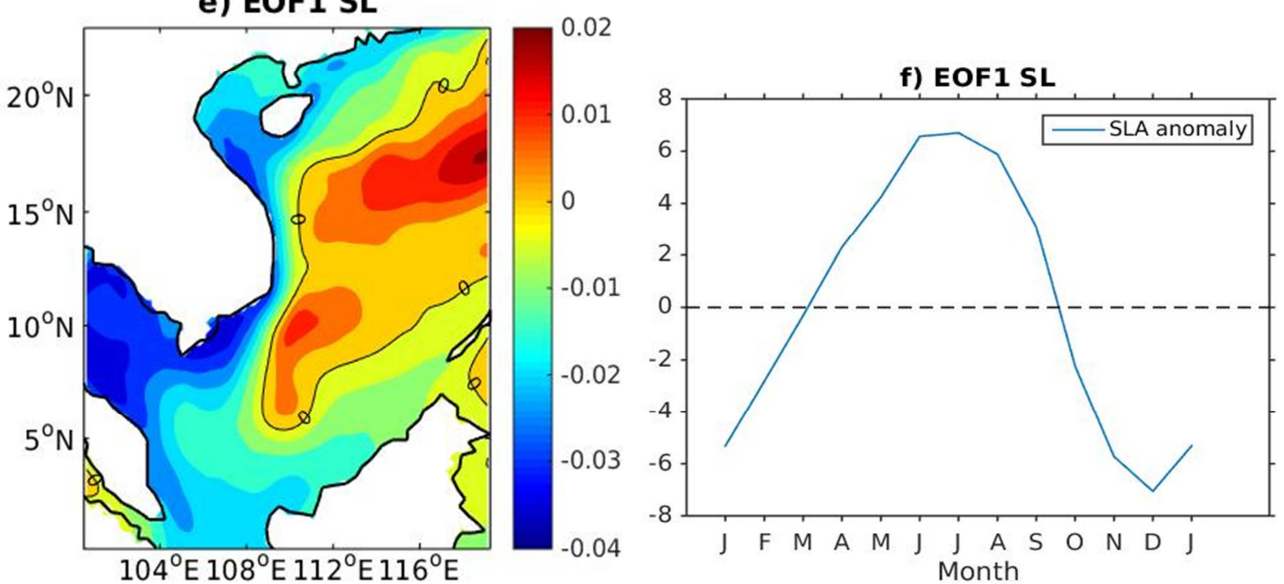

Figure 4. Spatial functions (a, c, e) and associated temporal functions (b, d, f) of the first and

second (only for SST) EOF seasonal modes of SST and SLA. The products between spatial and 
Ocean Sci. Discuss., https://doi.org/10.5194/os-2017-104

Manuscript under review for journal Ocean Sci.

Discussion started: 2 January 2018

(c) Author(s) 2018. CC BY 4.0 License. values.

To further analyze the SST seasonal changes, typical years are represented in four boxes, following the criteria of Qu (2001) based on mixed layer depths (boxes A to D in Fig. 5). A fifth box (E) was added to represent the region of high variability in the Gulf of Tonkin.

The results correspond to those of $\mathrm{Qu}$ and highlight the main influence of monsoon cycles on SST in boxes A and E, while box C (and B and D to a lesser extent) also seems to be influenced by the thermal advection described above.
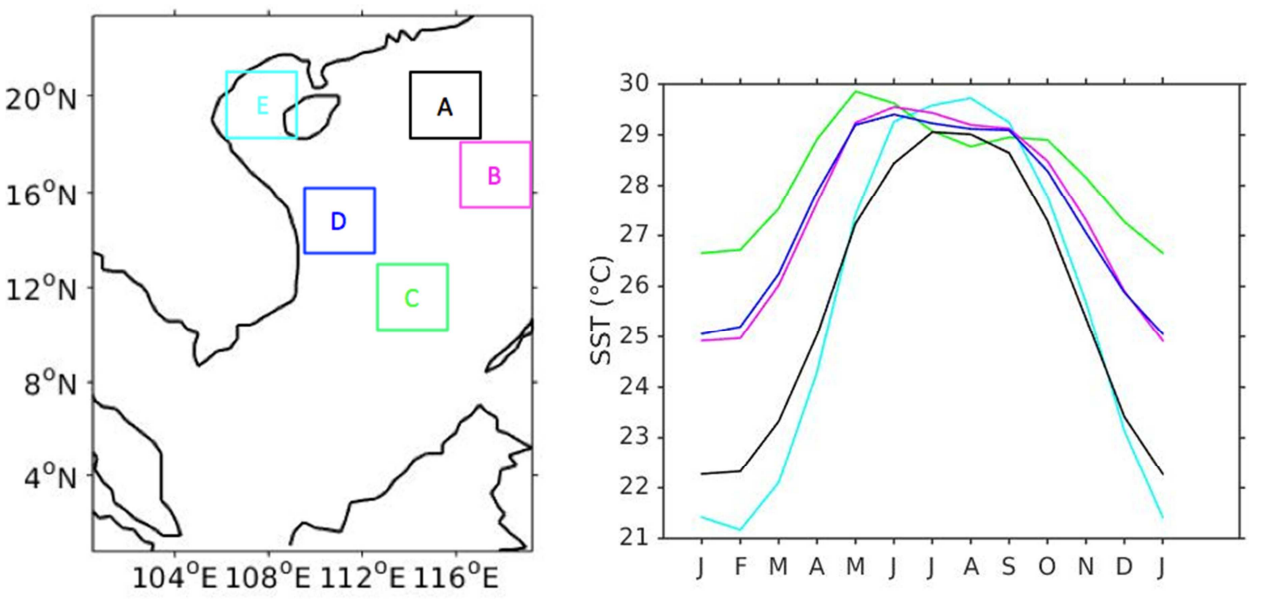

Figure 5. Locations of boxes (left) and time series of the relative SST monthly means (in ${ }^{\circ} \mathrm{C}$ ) over boxes A (black), B (magenta), C (green), D (blue) and E (cyan).

SLA. The first seasonal EOF mode on SLA accounts for $80 \%$ of the total variance of the signal (Fig. 4ef). The spatial function shows positive values in the central and eastern parts of the SCS and negative values in the western part of the basin. The temporal function reveals higher-than-average (up to $0.14 \mathrm{~m}$ ) SLAs in the summer in most of the basin and lower-than-average SLAs along the coastlines of Vietnam, Cambodia and Malaysia. In the winter, the situation reverses leading to negative anomalies over most of the basin and positive anomalies along the coasts. Interestingly, this EOF mode also emphasizes lower- 
Ocean Sci. Discuss., https://doi.org/10.5194/os-2017-104

Manuscript under review for journal Ocean Sci.

Discussion started: 2 January 2018

(c) Author(s) 2018. CC BY 4.0 License.

Vietnam eddy, although to a lesser extent). Logically, the timing of those seasonal SLA drops corresponds to the maximum development of the two eddies inferred from hydrographic observations $(\mathrm{Qu}, 2001)$. In addition, the seasonal sea level drops that are observed in the summer along the coasts are consistent with the upwelling-favorable surface winds that blow to the northwest at that time of the year (see below).

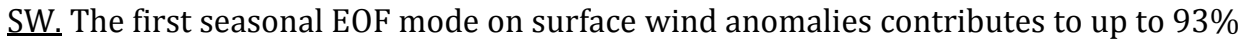
of the variance for both zonal $(\mathrm{U})$ and meridional $(\mathrm{V})$ components. The two temporal functions show an annual cycle, and the spatial functions show positive values over the entire region and more intense values over the sea (Fig. 6a-d). In the summer, the eastward (U) and northward (V) anomalies are then more intense (up to $17 \mathrm{~m} / \mathrm{s}$ ). The situation reverses in the winter with negative anomalies up to $10 \mathrm{~m} / \mathrm{s}$. The January-February-March (JFM) and June-July-August (JJA) mean wind vectors are shown in Figure 7, which stress the seasonal monsoon reversal to ease the interpretation of the EOF analysis performed separately on each wind component. The wind anomalies strongly depend upon the orographic features of the region: the seasonal wind anomalies are stronger above the sea. 
Ocean Sci. Discuss., https://doi.org/10.5194/os-2017-104

Manuscript under review for journal Ocean Sci.

Discussion started: 2 January 2018

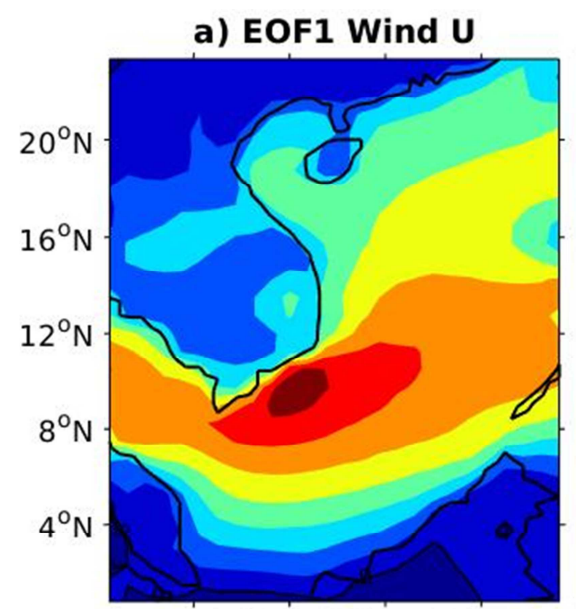

c) EOF1 Wind $v$

342

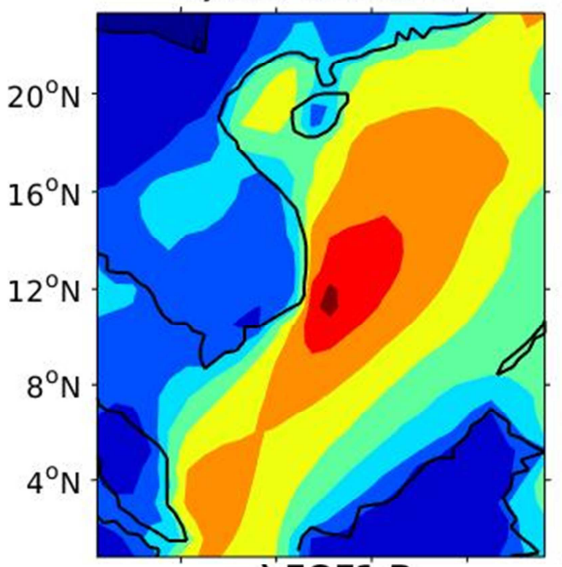

e) EOF1 P

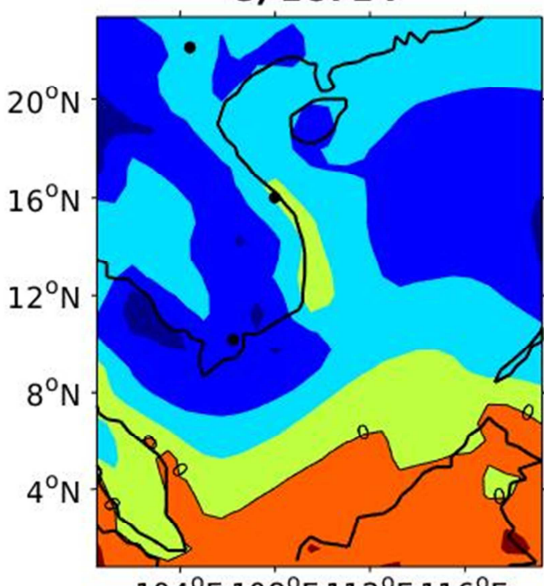

$104^{\circ} \mathrm{E} 108^{\circ} \mathrm{E} 112^{\circ} \mathrm{E} 116^{\circ} \mathrm{E}$

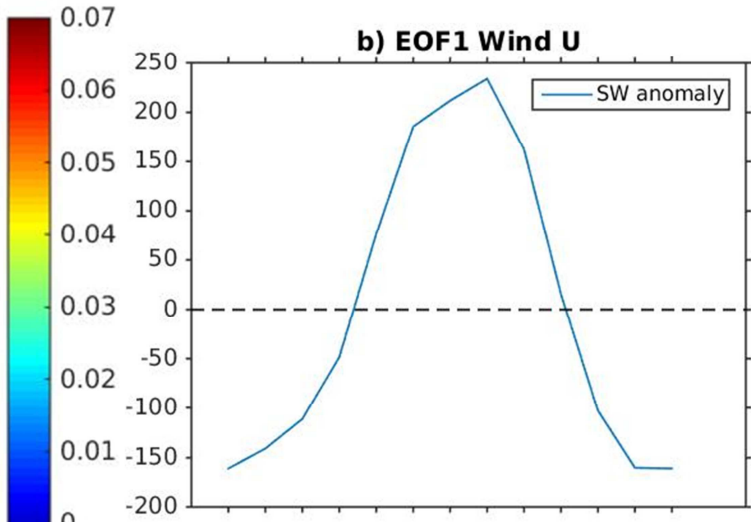

0
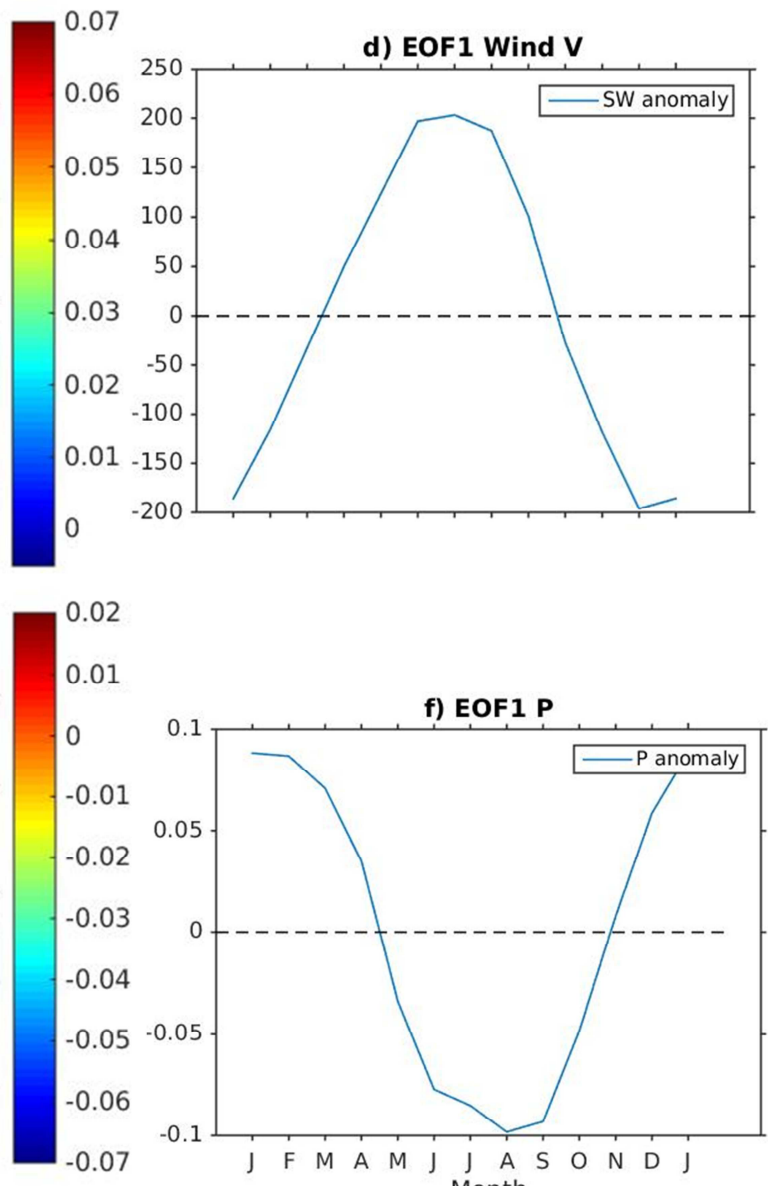

Figure 6. Spatial functions (a, c, e) and associated temporal functions (b, d, f) of the first

seasonal EOF modes on the $\mathrm{U}$ and $\mathrm{V}$ components of the surface wind, and P. The products

346 between the spatial and temporal functions denote anomalous $\mathrm{U}$ and $\mathrm{V}$ (in $\mathrm{m} / \mathrm{s}$ ) and $\mathrm{P}$ (in 

Figure 3e.

a) JFM

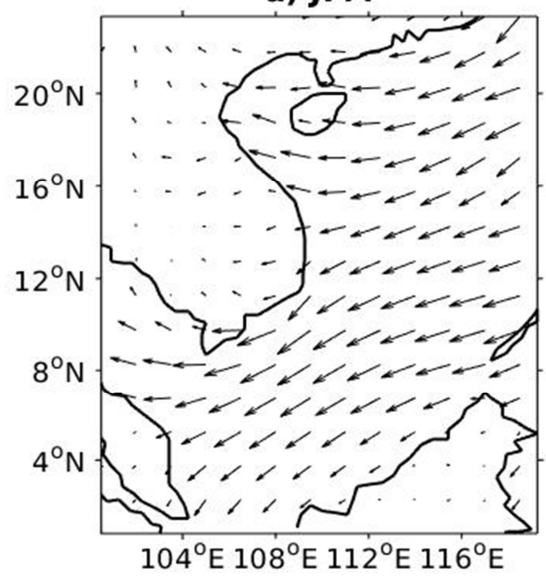

b) JJA

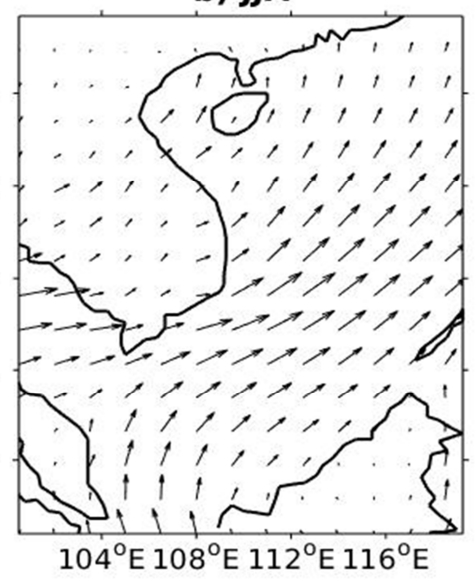

350

Figure 7. Mean surface wind in January-February-March (a) and June-July-August (b). The arrows denote the wind vectors, and the longest arrows equal $8 \mathrm{~m} / \mathrm{s}$.

$\underline{\mathrm{P}}$. The first seasonal EOF mode on P contributes to $69 \%$ of the total variance (Fig. 6ef). A clear annual cycle appears on the temporal function. North of $8^{\circ} \mathrm{N}$ during the summer, the entire region undergoes positive rainfall anomalies as intense as $6 \mathrm{~mm} / \mathrm{d}$, except along the central coastline of Vietnam where the anomalies are slightly lower, which possibly corresponds to the upwelling-favorable wind effects and relatively cold SST patterns near the coast (Chu et al., 1997). During the winter, the signs of the anomalies reverse and the region north of $8^{\circ} \mathrm{N}$ undergoes seasonal rainfall deficits compared to the mean.

The seasonal $\mathrm{P}$ anomalies relative to the means (see values in Table 1) of the three selected in situ stations are shown in Figure 8. The anomalous values can be as high as 40 $\mathrm{mm} / \mathrm{d}$ and as low as $-8 \mathrm{~mm} / \mathrm{d}$, with a tendency to depict annual, Dirac-like, and semi-annual functions at the Lục Yên, Đà Nẵng and Mỹ Tho stations, respectively. The results for the Lục Yên station and the peak observed in the autumn at the Đà Nẵng station are qualitatively similar to the observations (from different periods) by Nguyen et al. (2014). The authors 
Ocean Sci. Discuss., https://doi.org/10.5194/os-2017-104

Manuscript under review for journal Ocean Sci.

Discussion started: 2 January 2018 subtropical ridge and the intertropical convergence zone.

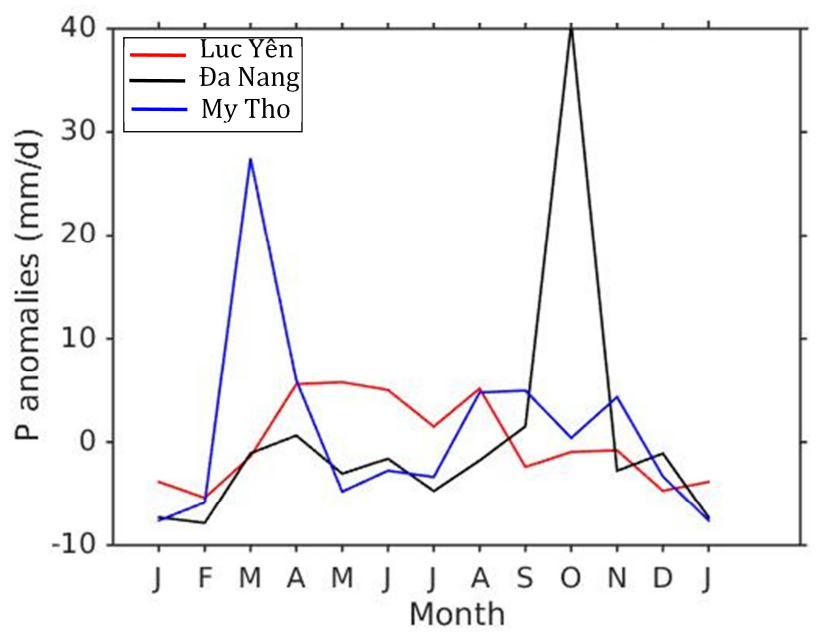

Figure 8. Seasonal variability of precipitation anomalies relative to the means from in situ land stations, Lục Yên (red), Đà Nẵng (black) and Mỹ Tho (blue). The station locations are denoted by black dots in Figures $3 \mathrm{e}$ and $6 \mathrm{e}$ (see also Table 1). The units are in mm/d.

WD. Figure 9 presents the seasonal variability relative to the means (see values in Table 1) of the water discharge from the Red River (at ST) and Mekong River (at CCV). The discharges observed at the ST station (red line) are much lower than those at the CCV station (black and blue lines), with anomalies ranging from $-1.10^{4}$ to $+2.10^{4} \mathrm{~m}^{3} / \mathrm{s}$. At the CCV station, the highest discharge flux is observed in September (from both gauge station and satellite measurements) with anomalies as high as $1.8 \times 10^{4}$ and $1 \times 10^{4} \mathrm{~m}^{3} / \mathrm{s}$ for the in situ and satellite data, respectively. The entire water discharge series shows a peak in the summer and a trough in the winter. This variability is probably driven by the monsoon dynamics with a peak in water flow during the rainy season (summer monsoon) and negative anomalies during the dry season (winter monsoon), as illustrated in Figures 6ef and discussed above.

To explain the different amplitudes between the satellite and gauge station data at the CCV Red River station (black and blue lines in Fig. 9), measurements over the common 
Ocean Sci. Discuss., https://doi.org/10.5194/os-2017-104

Manuscript under review for journal Ocean Sci.

Discussion started: 2 January 2018

(c) Author(s) 2018. CC BY 4.0 License. month lags in the peak and trough, for currently unknown reasons.

387

388

389

390

391

392

393

394

395

396

397

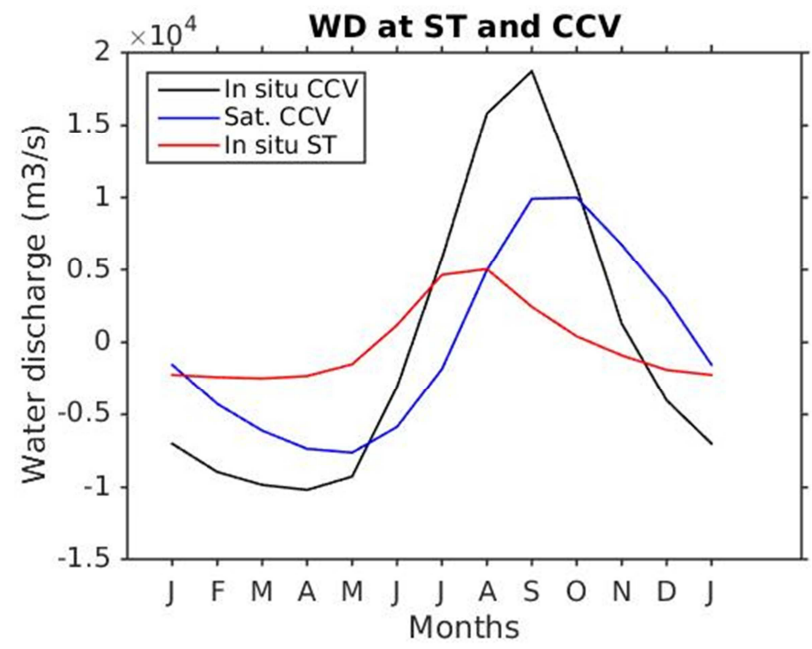

Figure 9. Seasonal variability of the water discharge (WD) anomalies relative to the means at the (Red River) ST station from gauge station measurements (period: 1960-2010) in red, and at the (Mekong River) CCV station from gauge station measurements (period: 19602002, in black) and satellite measurements (period 1996-2015) in blue. The units are in $10^{4}$ $\mathrm{m}^{3} / \mathrm{s}$. The mean values are reported in Table 1 .

\section{Interannual variability}

As noted in section 2, EOF analyses are performed to extract the main interannual variability and compare with ENSO indices. The maximum correlation coefficients at given lags between the interannual temporal function of the EOF and all (low-pass filtered) climate indices are listed in Table 2.

\begin{tabular}{|c|c|c|c|c|c|}
\hline \multirow{2}{*}{ Time series } & \multicolumn{5}{|c|}{ R (lag in months) } \\
\cline { 2 - 6 } & Niño1+2 & Niño3.4 & Niño4 & SOI & EMI \\
\hline SST EOF1 & $0.59(6)$ & $0.45(6)$ & $-0.38(-12)$ & $-0.44(-5)$ & $-0.40(12)$ \\
\hline SST EOF2 & $0.22(12)$ & $0.58(0)$ & $-0.55(2)$ & $0.55(1)$ & $-0.53(2)$ \\
\hline SLA EOF 1 & $0.34(0)$ & $0.70(2)$ & $0.78(3)$ & $-0.74(2)$ & $0.62(4)$ \\
\hline SW U EOF1 & $-0.51(3)$ & $-0.69(4)$ & $-0.64(5)$ & $0.65(5)$ & $-0.42(7)$ \\
\hline SW V EOF 1 & $0.60(0)$ & $0.74(2)$ & $0.58(3)$ & $-0.71(3)$ & $0.28(4)$ \\
\hline P EOF1 & $0.25(0)$ & $0.57(0)$ & $0.64(0)$ & $-0.60(0)$ & $0.49(2)$ \\
\hline
\end{tabular}


Table 2. Maximum correlation coefficients (R) at given lags (given in months in brackets) between the ENSO indices and reported interannual EOF time functions (as shown in Figs.

40011 and 13). A positive lag indicates that the indices lead the variable. All $\mathrm{R}$ values are significant at the $90 \%$ confidence level.

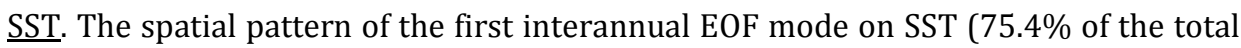
variance) is positive over the entire SCS with highest values along a northeast-southwest diagonal (Fig. 10a). The associated temporal function (Fig. 10b) shows a maximum correlation coefficient value of +0.59 with the Niño1 +2 index (Table 2) with an index lead of 6 months. Thus, it appears that 6 months after the mature phase of an Eastern Pacific El Niño event (represented by the Niño1+2 index, see section 2), a basin-wide SCS peak warming of SST occurs. This peak is especially clear during the strong events of 1986-87 and 1997-98 when the SST increased by up to 0.7 and $1.0^{\circ} \mathrm{C}$, respectively, in the central northern parts of the SCS.

The spatial pattern, the anomalous amplitude and the lag are quite similar to those of Chu et al. (1997) and Fang et al. (2006) that were obtained from different data sets and time periods. They further resemble the averaged February and August double-peak structures of the SCS SST composite anomalies derived from seven El Niño events covering 1950-2002 by Wang et al. (2006). The lagging response of SST to ENSO events (observed here for Niño1+2, and in Table 2 for Niño3.4, Niño4 and EMI) is described as a common feature in tropical oceans. Klein et al. (1999) and Wang et al. (2004) attribute this lag to the effect of the atmospheric bridge and the thermal inertia of the ocean mixed layer in the tropical Pacific. The second interannual EOF mode on SST (7.3\% of the variance) is represented by

420 positive spatial values in the SCS except near the Chinese and Vietnamese coasts and south 421 of Vietnam (Fig. 10c). The temporal function is best correlated to both the SOI and the Niño4 index $(R=-0.55)$ with lags of one and two months, respectively, which are considered to be 
Ocean Sci. Discuss., https://doi.org/10.5194/os-2017-104

Manuscript under review for journal Ocean Sci.

Discussion started: 2 January 2018

(c) Author(s) 2018. CC BY 4.0 License.

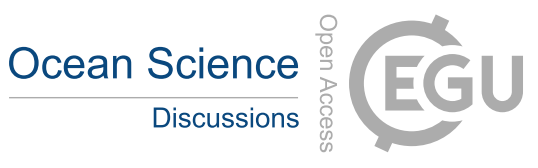

(c) $\underset{\mathrm{BY}}{(i)}$

424 during the strong EP-type El Niño events depicted in the first EOF mode, it indicates that all

425 El Niño events produced SST decreases of approximately $0.1^{\circ} \mathrm{C}$ in the eastern half of the

426 basin and SST increases of up to $0.2^{\circ} \mathrm{C}$ along the coasts and south of Vietnam. The La Niña

427 events, not clearly visible in the first EOF mode (as in Wang et al., 2006), led to an SST

428 increase in most of the SCS, except along the coast and south of Vietnam where the

429 temperatures decreased. The first interannual EOF mode on the wind stress curl (not shown

430 here), an alias for Ekman pumping, represents $40 \%$ of the total variance, and the related

431 time function is correlated with the Niño4 index $(\mathrm{R}=0.6)$. Interestingly, its spatial pattern

432 proves rather consistent with the second interannual EOF mode on SST, being favorable to

433 upwelling (downwelling) in the eastern (western) half of the basin during El Niño (and vice

434 versa for La Niña). 
Ocean Sci. Discuss., https://doi.org/10.5194/os-2017-104

Manuscript under review for journal Ocean Sci.

Discussion started: 2 January 2018

a) EOF1 SST

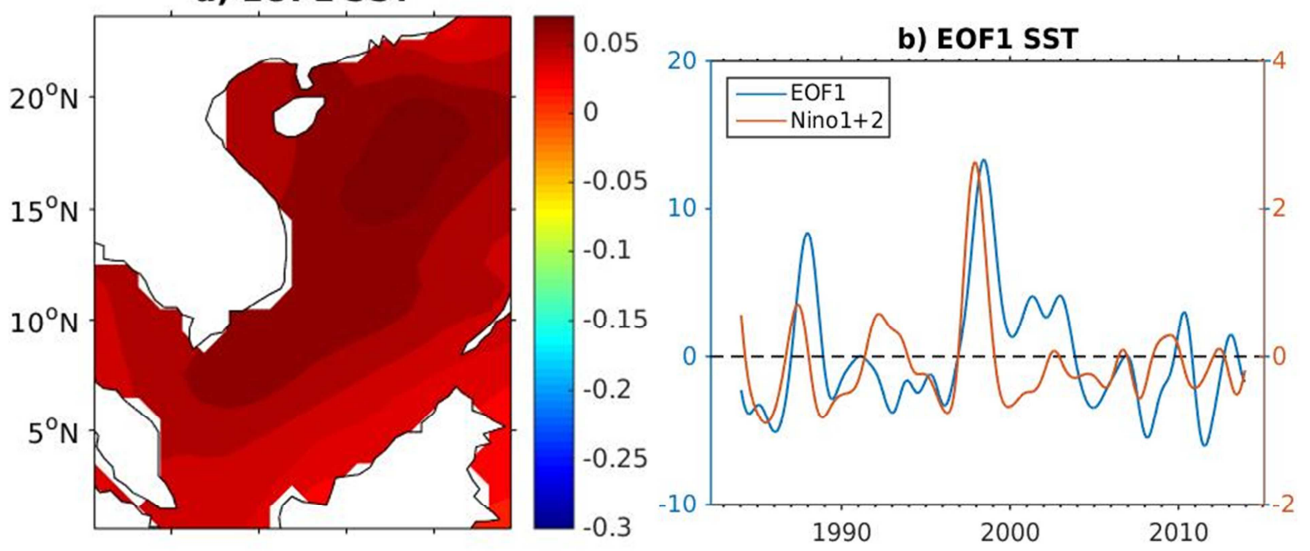

c) EOF2 SST

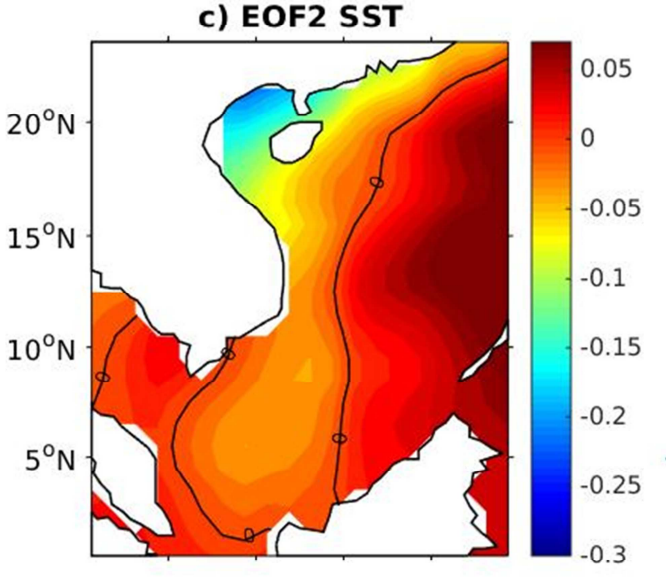

e) EOF1 SLA

436
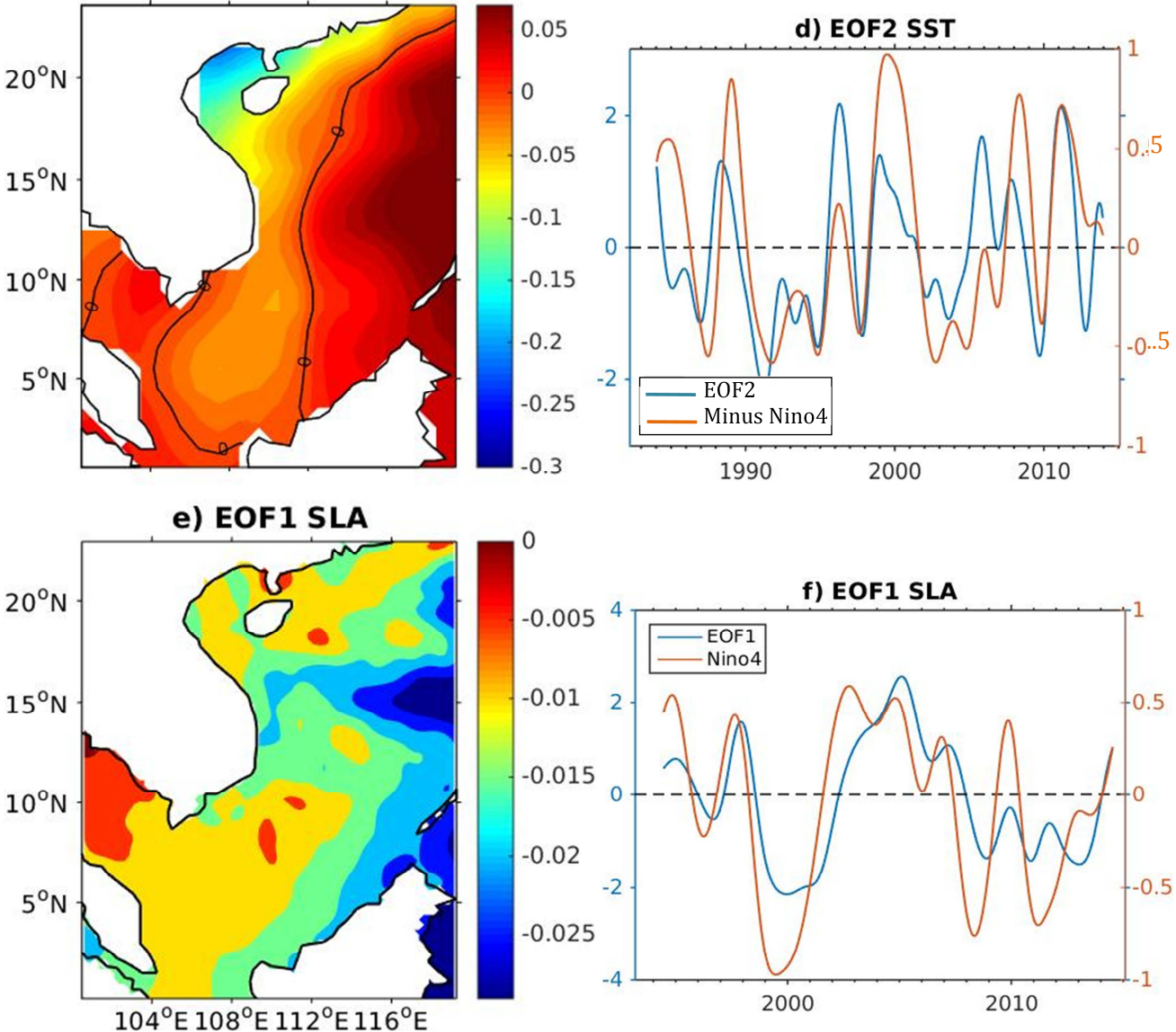

Figure 10. Spatial functions (a, c, e) and associated temporal functions (b, d, f) of the first and second interannual (only for SST) EOF modes on SST and SLA. The products between the spatial and temporal functions denote anomalous SSTs (in ${ }^{\circ} \mathrm{C}$ ) and SLAs (in m), 
Ocean Sci. Discuss., https://doi.org/10.5194/os-2017-104

Manuscript under review for journal Ocean Sci.

Discussion started: 2 January 2018

441 respective to the mean values. The Niño1+2 (b, in blue) and the Niño4 SST indices (d, f, in

442 red) are plotted over the time functions. The Niño4 index is reversed on panel (d). For

443 clarity, the temporal functions and the indices are filtered again with the H25 filter but are

444 described in the text with the TY-H13 filtration method.

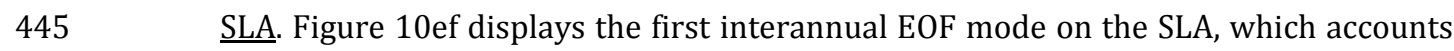

446 for $48.1 \%$ of the total variance. The spatial patterns of this EOF mode are characterized by

447 the same negative sign throughout the basin (but with large horizontal gradients in

448 amplitude), which indicates that SLAs occur consistently over the entire SCS. The associated

449 temporal function is highly correlated $(\mathrm{R}=+0.78$; lag=3 months) with the Niño4 index (Table

450 2). This EOF mode reveals that the sea level drop is largest three months after the mature

451 phase of an El Niño event. The negative SLA can be as strong as 5-10 cm in the eastern part

452 of the basin and along approximately $15^{\circ} \mathrm{N}$. A reverse situation occurs during a La Niña year.

453 Rong et al. (2007) found similar spatial and temporal patterns for the period 1993-2005

454 with high correlation with the SOI (the only index tested). The observed anomalies are

455 consistent with the results presented by Fang et al. (2006) based on 1993-2003 satellite

456 altimetry data and with the results from a data assimilation model ran for the period 1993-

4572002 (Wu and Chang, 2005).

458 SW. The first interannual EOF mode on zonal wind contributes to $64 \%$ of the total

459 variance of the signal (Fig. 11ab). The spatial function is positive in the southern part of the

460 region and negative north of approximately $14^{\circ} \mathrm{N}$. The temporal function shows a high

461 negative correlation of $\mathrm{R}=-0.64$ (Table 2) with the Niño4 index leading by five months (and

462 R=-0.69 with Niño3.4 leading by 4 months). This result indicates that 4-5 months after the

463 mature phase of an El Niño event, the eastward winds reach their maximal weakening (up to

$464-4 \mathrm{~m} / \mathrm{s}$ ) south of $14^{\circ} \mathrm{N}$ and get stronger (up to $4 \mathrm{~m} / \mathrm{s}$ ) north of $14^{\circ} \mathrm{N}$. The situation reverses

465 during La Niña phases. 
Ocean Sci. Discuss., https://doi.org/10.5194/os-2017-104

Manuscript under review for journal Ocean Sci.

Discussion started: 2 January 2018

(c) Author(s) 2018. CC BY 4.0 License.

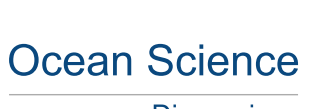

Discussions

(c) (1)

466 The first interannual EOF mode on meridional wind explains $49.4 \%$ of the total

467 variance with a positive spatial pattern north of approximately $6^{\circ} \mathrm{N}$ (Fig. 11c). The

468 corresponding temporal function is correlated with the SOI $(\mathrm{R}=-0.71)$ and the Niño3.4 index

$469(\mathrm{R}=+0.74)$, with indices leading by 2-3 months. All types of El Niño events trigger an increase

470 in northward winds (e.g., up to $4 \mathrm{~m} / \mathrm{s}$ during the $1997-98$ event) north of $6^{\circ} \mathrm{N}$ and a decrease

471 of the same amplitude south of $6^{\circ} \mathrm{N}$. These ENSO-related surface wind anomalies are

472 consistent with the results obtained by Wang et al. (2006) that were based on a composite

473 analysis, and those by Cheng et al. (2016) that were based on an EOF analysis, both obtained

474 from different wind field products and (shorter) time periods. 
Ocean Sci. Discuss., https://doi.org/10.5194/os-2017-104

Manuscript under review for journal Ocean Sci.

Discussion started: 2 January 2018
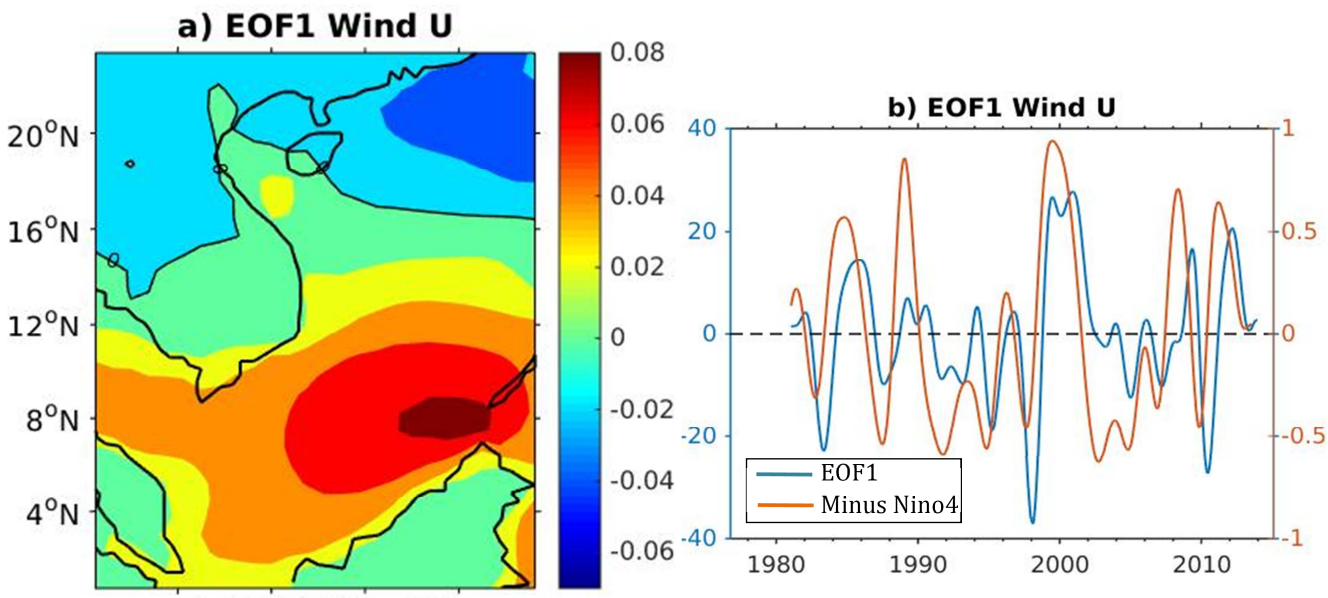

\section{c) EOF1 Wind $V$}

476
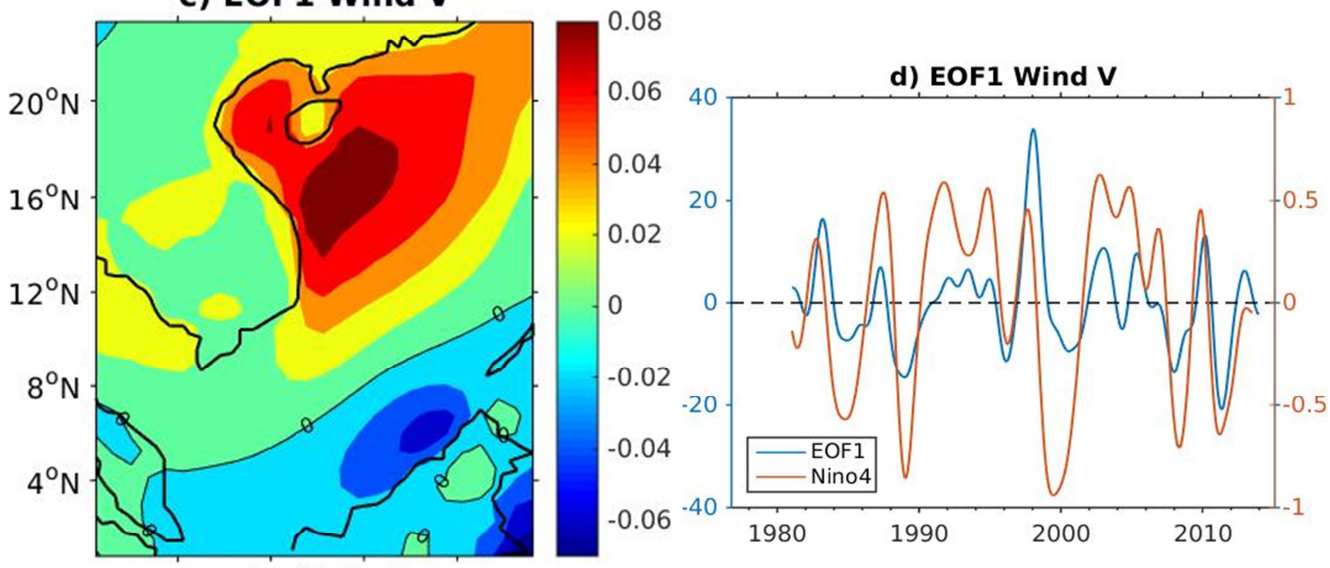

e) EOF1 P
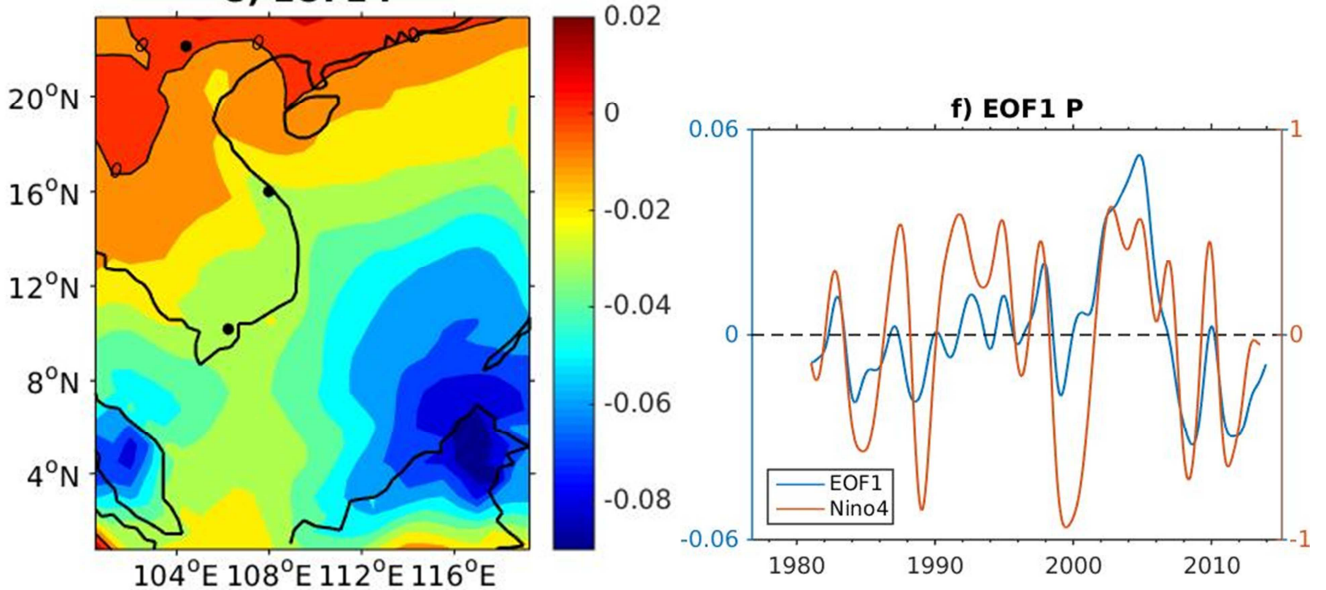

Figure 11. Spatial functions (a, c, e) and associated temporal functions (b, d, f) of the first interannual EOF modes on the $\mathrm{U}$ and $\mathrm{V}$ wind components and $\mathrm{P}$. The products between the 
Ocean Sci. Discuss., https://doi.org/10.5194/os-2017-104

Manuscript under review for journal Ocean Sci.

Discussion started: 2 January 2018

(c) Author(s) 2018. CC BY 4.0 License.

481 respective to the mean values. The Niño4 SST index is plotted over the time functions. The Niño4 index is reversed on panel (b). For clarity, the temporal functions and the indices are filtered again with the H25 filter here but are described in the text with the TY-H13 filtration method. The black dots in Figure 11e are the same as those in Figure 3e.

Figure 12 represents the composites of the anomalous wind vectors for the winter during four strong El Niño events, noted JFM, and for the following summer, noted JJA. The four El Niño events considered here are the 1982-83, 1986-87, 1991-92, and 1997-98 events, which were selected according to the studies of Chiodi and Harrison $(2010,2013)$. The authors identified the abovementioned El Niño events as strong events that were characterized by strong peaks in both Niño3.4 SST and outgoing long-wave radiation (OLR) anomalies over the eastern-central equatorial Pacific. Figure 12a shows that the anomalous winds were blowing N-NE, and when compared to the mean conditions in JFM when the winds blow S-SW (Fig. 7a), this potentially leads to a weakened winter monsoon. The anomalous JJA composites (Fig. 12b) show anomalous winds blowing S-SW, compared to the mean conditions in JJA (when the winds blow N-NE (Fig. 7b)). Furthermore, each JFM and JJA of each strong El Niño year were tested separately (not shown here), and the results showed the same wind patterns as the JFM and JJA composites. Figure 12 compares the anomalies over three months of a composite of strong El Niño events and is thus not directly comparable with Figure 11abcd where the anomalies are presented relative to the long-term mean, comprising all types of El Niño and La Niña events. Lastly, the same analyses were performed on four La Niña years (1983-84, 1988-89, 1995-96, 1998-99). The surface winds showed almost reversed patterns from the ones observed for El Niño years (not shown here). The anomalous JFM composites for La Niña events showed anomalous wind blowing S-SW, and the anomalous JJA composites showed anomalous wind blowing N-NE. 
a) JFM

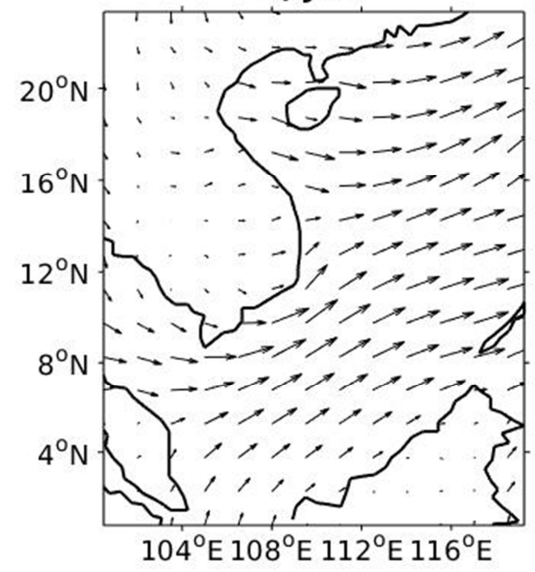

b) JJA

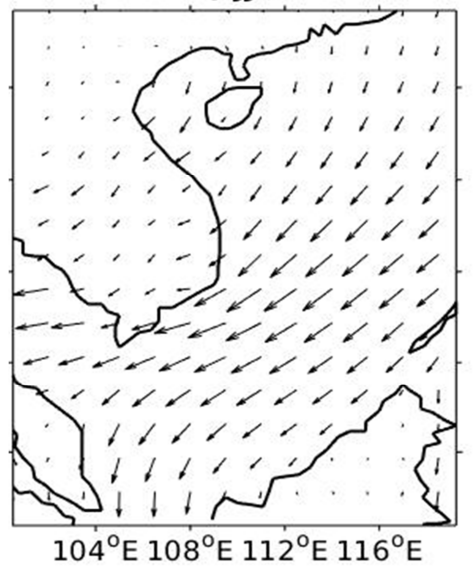

506 Figure 12. El Niño composites of the anomalous surface wind vectors in JFM (a) and JJA (b) computed for 1983, 1987, 1992, and 1998, representing the 1982-83, 1986-87, 1991-92, and 1997-98 El Niño events, respectively. The arrows denote the vectors, with the longest arrows equal to $1 \mathrm{~m} / \mathrm{s}$.

$\underline{\mathrm{P}}$. The spatial function of the first interannual EOF mode on P $(48.4 \%$ of the total variance) is negative over most of the region, except north of Vietnam, Laos and along the Chinese coast, and it shows maximum values in the southeastern part of the region (Fig. 11e). The temporal function that is correlated with the Niño4 index ( $\mathrm{R}=0.64$ at 0 lag) reveals that precipitation decreases during El Niño events and increases during La Niña phases. For the case of the 1997-98 event, which was one of the strongest ENSO events ever recorded, the amount of rainfall associated with EOF 1 (again representing only $48.4 \%$ of the variance) reduces by as much as $1.6 \mathrm{~mm} / \mathrm{d}$ in the southeast region, which is a reduction of $28 \%$ relative to the mean value (Fig. 3f). The important $\mathrm{P}$ decreasing rate that was observed can be explained by the eastward shift in convective activity in the equatorial western Pacific during El Niño phases. Such shift leads to altered Walker circulation, generating a subsidence area over the SCS (Wang et al., 2006). 
Ocean Sci. Discuss., https://doi.org/10.5194/os-2017-104

Manuscript under review for journal Ocean Sci.

Discussion started: 2 January 2018

with Niño3.4 ranging from $\mathrm{R}=-0.19$ to -0.45 . As an example, at station Đà Nẵng where $\mathrm{R}=-$ 0.45, the rainfall decreases during El Niño phases by up to $4 \mathrm{~mm} / \mathrm{d}$ during the 1997-98 El Niño event (which is $70 \%$ of the mean). Nguyen (2014) also demonstrated that temperature and rainfall variability are more strongly linked to ENSO events at lower latitudes of Vietnam for the period 1971-2010. A study of the gridded precipitation data over the mainland of Southeast Asia (1980-2013) that was undertaken by Räsänen et al. (2016) confirmed the stronger influence of ENSO in the southern parts of the study area with high correlation to ENSO during the spring of the decaying year.

WD. No obvious correlation was found between the interannual water discharge at the ST Red River station and ENSO indices when the period 1960-2010 was considered. However, when examining the period prior to the Hoa Binh Dam impoundment (from 1960 to 1978), the signal shows a statistically significant correlation to Niño4 ( $R=-0.47$ at 12 month lag). This suggests that the dam, by regulating the water flow according to the dry/wet seasons and demand, may interfere with the interannual signal. At the CCV Mekong station, both the 1960-2002 in situ and 1996-2002 satellite anomalies are correlated with the SOI (+0.51 and +0.53 , respectively, with an SOI lead of 6 months) and with the Niño4 index (-0.42 and -0.50 with 7-8-month lags, respectively). As an example, when considering the $1997-98$ event, the water discharge is reduced by approximately $4000 \mathrm{~m}^{3} / \mathrm{s}$ (i.e., $34 \%$ of the mean) approximately 7 to 8 months after the event. Xue et al. (2011) showed a similar connection between ENSO and Mekong runoff (at Pakse, Laos, approximately $400 \mathrm{~km}$ upstream of the CCV station) for the period from 1993-2005. It is important to consider the WD data with caution as the precipitation anomalies over the entire Red River and Mekong

546 River watersheds $\left(143,000\right.$ and $795,000 \mathrm{~km}^{2}$, respectively) are integrated and may relate 547 processes that occur outside of the area considered here and potentially far away from any 548 ENSO influence. 
Trends are calculated over the total length of each dataset. Since the series differ in

551

552

553

554

555

556

557

558

559

560

561

562

563

564

565

566

567

568

569

570

571

572 lengths, they are also calculated over a common 27-year period (1979-2006) for most of the datasets ( $\mathrm{P}$ in situ, $\mathrm{P}$ and SW products from ERA-interim, WD at ST). No significant differences appeared between the trends that were calculated over the entire length of the dataset and over the common period (both values are discussed when possible).

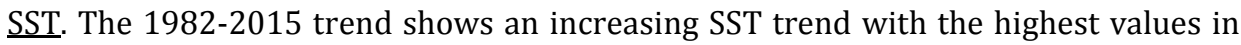
the northeastern part of the basin and maximum values west of the Luzon Strait and along the Borneo coastlines of approximately $0.24^{\circ} \mathrm{C} /$ decade (or a total rise of $0.82^{\circ} \mathrm{C}$ of for the period 1982-2015). A small SST decrease is observed along a very narrow coastal band off central Vietnam and in the northern part of the Gulf of Tonkin of about $-0.06^{\circ} \mathrm{C}$ per decade (Fig. 13a). The computation of the wind stress curl trend (not shown here), an alias for Ekman pumping trend, proves to be inconsistent with the spatial variations and even with the sign of the SST trends. Fang et al. (2006) also found higher warming rates in the northern deep basin and lower rates in the southern SCS with an area-mean SCS SST trend of approximately $0.26^{\circ} \mathrm{C}$ /decade (from 1982 to 2004). They further identified a period of faster warming rates between 1993 and 2003 with a rate up to $0.50 \pm 26^{\circ} \mathrm{C} /$ decade. Based on the observed and simulated SCS SST from 1977 to 2013, Mei and Xie (2016) found similar rising rates of SST of approximately 0.18 to $0.25^{\circ} \mathrm{C} /$ decade. For the $1960-1990$ period, Casey and Cornillon (2001) calculated a global ocean mean rate of $0.14 \pm 0.04^{\circ} \mathrm{C} /$ decade. Assuming that the recent (although different) three-decade trends can be compared, our results indicate that the 1982-2015 SCS warming rate is approximately 1.7 times greater than the 19601990 global mean rate of Casey and Cornillon (2001), and approximately 2.2 times greater than the 1971-2010 global mean rate discussed by the IPCC (2014).

As a cautionary note, it is important to keep in mind that large discrepancies exist between the published estimates of 21st century SST trends, especially in the tropical IndoPacific. These discrepancies seem to partly result from varying estimations of ENSO 
Ocean Sci. Discuss., https://doi.org/10.5194/os-2017-104

Manuscript under review for journal Ocean Sci.

Discussion started: 2 January 2018

(c) Author(s) 2018. CC BY 4.0 License.

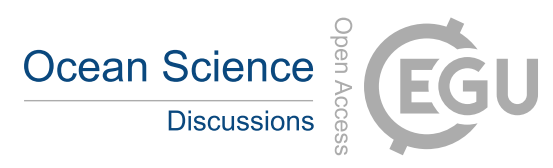

(c) (i)

576 influence in the computation of long-term trends, as discussed in Solomon and Newman

577 (2012). The influence of ENSO on the trend computation is illustrated in the last paragraph

578 of this section. 
a) Trend SST

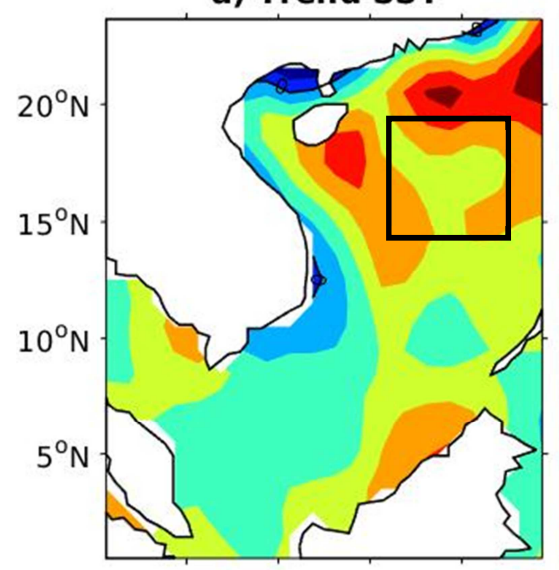

c) Trend Wind $U$

580

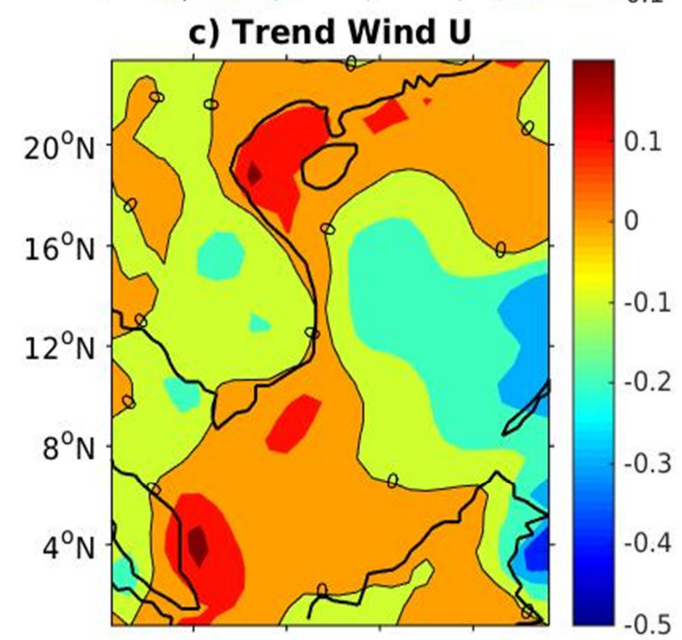

e) Trend SW

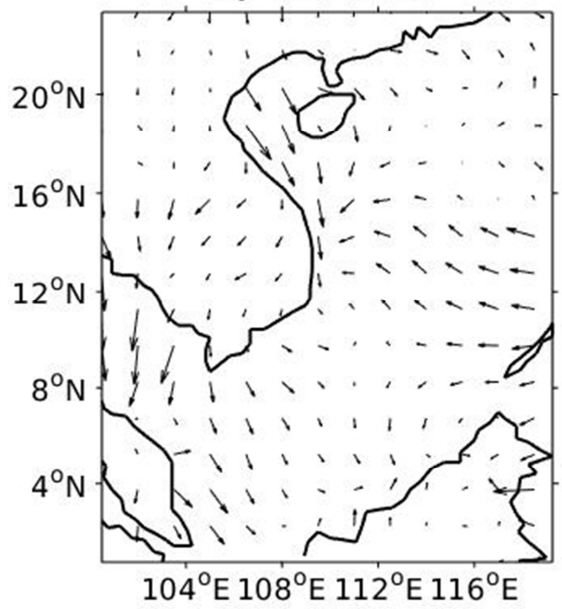

b) Trend SLA

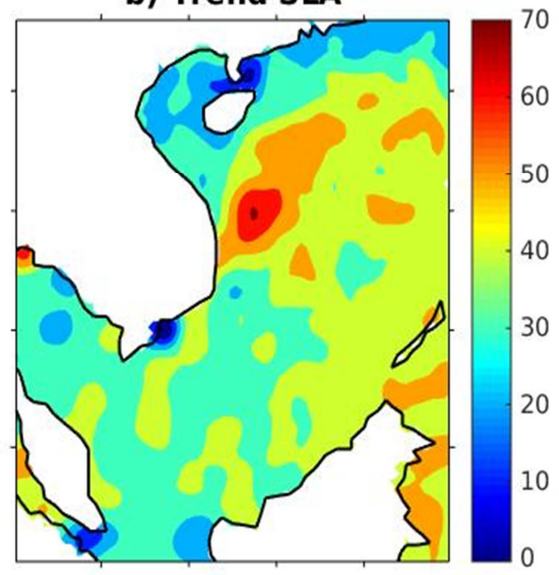

d) Trend Wind V

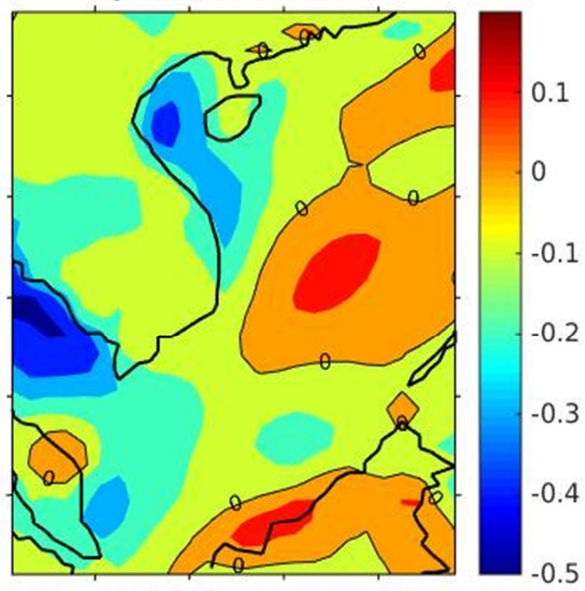

f) Trend $\mathbf{P}$

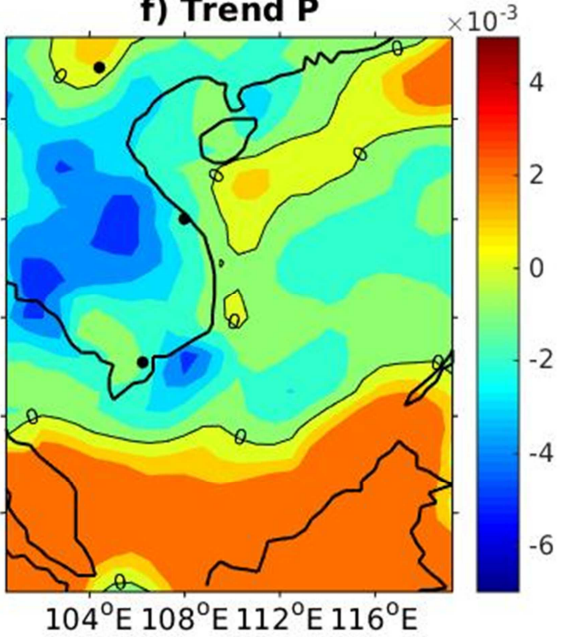

Figure 13. Trends of SST, SLA, surface wind components ( $U$ and $V)$ and vectors, and P (a, b, 
Ocean Sci. Discuss., https://doi.org/10.5194/os-2017-104

Manuscript under review for journal Ocean Sci.

Discussion started: 2 January 2018

584 The arrows denote the wind vectors, and the longest arrows are equal to $1 \times 10^{-3} \mathrm{~m} / \mathrm{s} / \mathrm{decade}$.

585 The color codes differ between the figures. The trends in the black square of Figure 13a are

586 discussed in the main text.

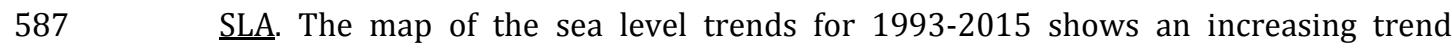
588 throughout the SCS basin with high spatial variability from 3 to $70 \mathrm{~mm} /$ decade and a mean 589 rising rate of approximately $41 \mathrm{~mm} /$ decade (Fig. 13b). A tongue of rapidly increasing rates is 590 observed from 14 to $20^{\circ} \mathrm{N}$ and along the longitudes 110 to $116^{\circ} \mathrm{E}$, corresponding to the 591 location of the minimum of MDT (observed in Fig. 2c). This finding suggests that the sea level 592 must be rising in the low center of the cyclonic loop current that is generated by the 593 intrusion of a branch of the Kuroshio Current through the Luzon Strait (Farris and Wimbush, 594 1996; Ho et al., 2000), which results in a slowdown of the related Luzon Strait and East 595 Vietnam cyclonic eddies. Peng et al. (2013) found similar sea level rise rates of 596 approximately $39 \mathrm{~mm} /$ decade for the period 1993-2009 using the same data product. These 597 results are, as well as the results found here, faster than the global mean rate of sea level rise 598 of $28 \pm 0.4 \mathrm{~mm} /$ decade (obtained for the period 1993-2003 with the TOPEX/Poseidon 599 altimeter) (Cazenave and Nerem, 2004) and the global mean sea level for 1993-2015 of 600 approximately $3.3 \mathrm{~mm} /$ decade that was recently obtained by Dieng et al. (2017). In line with 601 the analysis of Meyssignac et al. (2012), Cheng et al. (2016) indicated that the PDO 602 contributed to $72 \%$ of the total sea-level rise in the SCS during the 1993-2012 period. The 603 authors suggested that the intensification of the easterly winds associated with the PDO in 604 the last two decades leads to the increase in the steric sea level by deepening the 605 thermocline in the Western Tropical Pacific. Finally, they indicated that the remaining 28\%

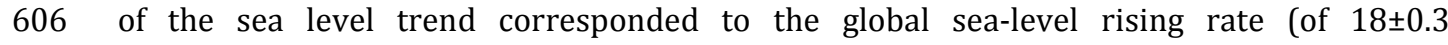
$607 \mathrm{~mm} /$ decade).

$608 \underline{\mathrm{SW}}$. The trends of the two wind components (Fig. 13cd) range from -0.48 to +0.18 
Ocean Sci. Discuss., https://doi.org/10.5194/os-2017-104

Manuscript under review for journal Ocean Sci.

Discussion started: 2 January 2018

(c) Author(s) 2018. CC BY 4.0 License.

6102015 in the northern and southern parts of the region and along the Vietnamese coastline

611 (reduced westward winds). Over the common period of measurements from 1979 to 2006,

612 the SW trends range from -4.3 to $1.710^{-2} \mathrm{~m} / \mathrm{s} / \mathrm{yr}$. The meridional component seems to

613 mainly weaken over the region, except in the eastern part of the SCS and above Borneo.

614 These results are consistent with the results from Fang (2006), who found an area-mean

615 trend of the zonal component of $0.56 \pm 35 \mathrm{~m} / \mathrm{s} /$ decade for the period 1993-2003. However,

616 we did not find an obvious trend for the meridional component. Part (not estimated here) of

617 the observed trend in the zonal wind is directly linked to the phase of the PDO, as suggested

618 by England et al. (2014) and others, since trade winds have considerably strengthened over

619 the past two decades. Figure 13e summarizes Figures 13cd in a vector form and shows that

620 the maximum rate of the trend is $1 \times 10^{-2} \mathrm{~m} / \mathrm{s} /$ decade, which occurs toward the south along

621 the Vietnamese coastlines and in the Gulf of Thailand.

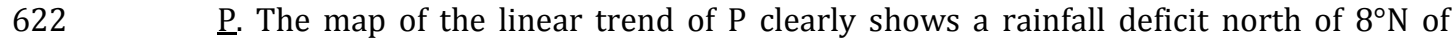
623 approximately $6 \mathrm{~mm} / \mathrm{d} /$ decade over the period considered (1979-2015), with maximum 624 values inland (Fig. 13e). Over the common period of measurements from 1979 to 2006, the 625 decreasing trend is approximately $-6.8 \mathrm{~mm} / \mathrm{d} /$ decade. The Lục Yên station also shows a 626 decreasing rainfall trend $\left(-2.64 \times 10^{-1} \mathrm{~mm} / \mathrm{d} /\right.$ decade $)$. However, the Đà Nẵng and Mỹ Tho 627 stations both show increasing precipitation trends with rates of $1.48 \times 10^{-1}$ and $6.73 \times 10^{-1}$ $628 \mathrm{~mm} / \mathrm{d} /$ decade, respectively. So far, we are not able to determine the origin of the observed 629 discrepancies between the satellite and in situ measurements (as well as the discrepancies 630 about the mean, as mentioned in section 2). Comparison with other satellite products is 631 recommended here. For the period 1961 to 1998, Manton et al. (2001) also showed that the 632 number of rain days over land (at least $2 \mathrm{~mm}$ of rain) has significantly decreased throughout 633 Southeast Asia. They associated this decrease with the predominance of El Niño events since 634 the mid-1970s (Trenberth and Hoar, 1997). 

Red River station, the water flux declined by $-520 \mathrm{~m}^{2} / \mathrm{s} /$ decade (representing $1.5 \%$ of the mean water discharge) over the period of 1960-2010. For the common period of measurement (1979 to 2006), the water flux declined by approximately $-420 \mathrm{~m}^{2} / \mathrm{s} /$ decade. This decreasing trend has also been emphasized by Vinh et al. (2014); it is partially due to 640 the impoundment of the Hoa Binh Dam in the late 1980s, which has decreased the water 641 flow since then. The trends at the CCV Mekong station also showed decreasing rates of -1220 $\mathrm{m}^{3} / \mathrm{s} /$ decade $\left(0.98 \%\right.$ of the mean WD) and $-1340 \mathrm{~m}^{3} / \mathrm{s} /$ decade $(0.87 \%$ of the mean WD) for 643 satellite and in situ data, respectively. Lu and Siew (2006) investigated the disruption in 644 water discharge at stations on the Lower Mekong River that was induced by the cascade 645 dams in the upper part of the main stream of the Mekong River and found a declining trend during the dry season. Furthermore, Xue et al. (2011) showed that the runoff of the lower 647 Mekong River was more closely connected to precipitation and ENSO in the post-dam period 648 (1993-2005) than in the pre-dam period (1950-1993). Distinguishing and isolating an effect from another one (precipitation, water use and water regulation of a dam, ENSO) on water 650 discharge would provide crucial information on the behavior and possible forecasting of a 651 trend. for not only the slight trend discrepancies observed between the literature and our results found for each ECV but also the way the timing and the amplitude of ENSO may affect the computation of long-term trends. To illustrate this issue, the 25-month Hanning filtered SST and the corresponding linear trends were computed over the box $14.5-19.5^{\circ} \mathrm{N}, 112.5-$

$657117.5^{\circ} \mathrm{E}$ roughly centered in the middle of the northern SCS (see the black square in Fig. 658 13a). Looking at Figure 14, the large SST anomalies that are characteristic of ENSO events (see the ENSO indices in Fig. 10ab) clearly impact the computation of the linear trends. To 
Ocean Sci. Discuss., https://doi.org/10.5194/os-2017-104

Manuscript under review for journal Ocean Sci.

Discussion started: 2 January 2018

(C) Author(s) 2018. CC BY 4.0 License.

Discussions

(c) $\underset{\mathrm{BY}}{(i)}$

661 then removed, and the linear trends were recomputed. Ignoring these four El Niño years

662 increased the SST trends by as much as $1.4^{\circ} \mathrm{C} /$ decade (from $1.0610^{-1}{ }^{\circ} \mathrm{C} /$ decade to $1.5310^{-1}$

$663{ }^{\circ} \mathrm{C} /$ decade).

664

665

666

667

668

669

670

671

672

673

674

675

676

677

678

679

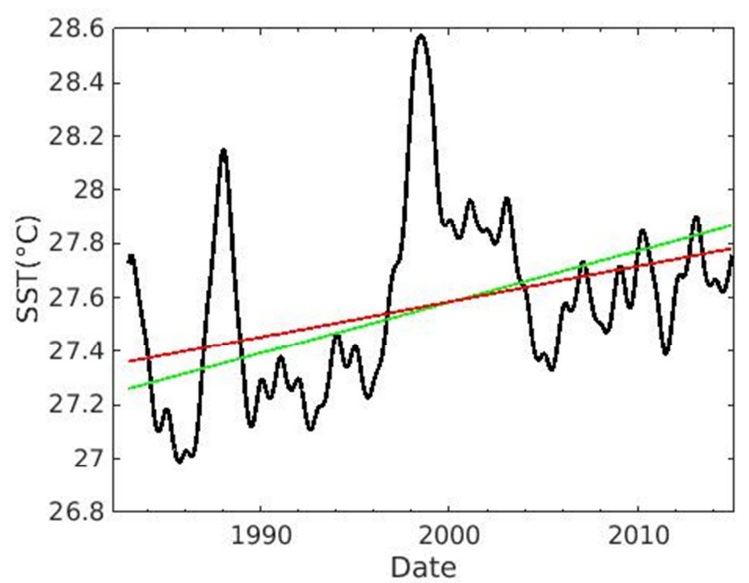

Figure 14. Time series of the 25-month Hanning filtered SST averaged over the box 14.5$19.5^{\circ} \mathrm{N}, 112.5-117.5^{\circ} \mathrm{E}$ (in black), the corresponding linear trend (in red) and the linear trend corresponding to the series shortened by four El Niño years (1987-88 and 1997-98) (in green). The location of the box is denoted by the black square in Figure 13a.

\section{Conclusion and discussion}

In this study, we successively analyze the long-term means, standard deviations, seasonal and interannual (mostly ENSO-related) variability and long-term trends of five key ECVs (sea surface temperature, sea level anomaly, surface wind, precipitation, and water discharge) to further document, validate, corroborate and/or complete the current scientific knowledge on the climate variability in the South China Sea.

The analysis of the first (or first two) EOF mode(s) on each ECV clearly exhibits the seasonal variability of the SCS under the influence of monsoon. In the summer, the SST is found to increase throughout the basin, the SLA increases in the central and eastern parts of the basin, positive rainfall anomalies are observed north of $8^{\circ} \mathrm{N}$, the eastward and northward 
Ocean Sci. Discuss., https://doi.org/10.5194/os-2017-104

Manuscript under review for journal Ocean Sci.

Discussion started: 2 January 2018

680

681

682

683

\begin{tabular}{|c|c|c|c|c|c|c|}
\hline & $\begin{array}{c}\text { SST } \\
1982-2015\end{array}$ & $\begin{array}{c}\text { SLA } \\
1993 / 2015\end{array}$ & $\begin{array}{c}\text { Taux } \\
1979-2015\end{array}$ & $\begin{array}{c}\text { Tauy } \\
1979-2015\end{array}$ & $\begin{array}{c}\mathrm{P} \\
1979-2015\end{array}$ & \begin{tabular}{l}
\multicolumn{1}{c}{ WD } \\
ST: $1960-$ \\
2010 \\
CCV \\
satellites: \\
1996-2015 \\
CCV in situ: \\
1960-2002
\end{tabular} \\
\hline $\begin{array}{l}\text { El Niño } \\
\text { events }\end{array}$ & $\begin{array}{c}\text { Increase } \\
\text { basin-wide } \\
\text { during EP }\end{array}$ & $\begin{array}{c}\text { Decrease } \\
\text { mostly in } \\
\text { the East }\end{array}$ & $\begin{array}{c}\text { Increase } \\
\text { north of } \\
14^{\circ} \mathrm{N}, \\
\text { decrease } \\
\text { to the } \\
\text { South } \\
\end{array}$ & $\begin{array}{c}\text { Increase } \\
\text { north of } \\
6^{\circ} \mathrm{N}, \\
\text { decrease } \\
\text { to the } \\
\text { South } \\
\end{array}$ & $\begin{array}{l}\text { Decrease } \\
\text { in the } \\
\text { South-East } \\
\text { region }\end{array}$ & $\begin{array}{c}\text { CCV: } \\
\text { Decrease } \\
\text { of water } \\
\text { discharge }\end{array}$ \\
\hline $\begin{array}{c}\text { Trends per } \\
\text { decade }\end{array}$ & $+0.24^{\circ} \mathrm{C}$ & $+41 \mathrm{~mm}$ & $\begin{array}{c}-0.48 \text { to } \\
+0.18 \mathrm{~m} / \mathrm{s}\end{array}$ & $\begin{array}{c}-0.5 \text { to }+0.1 \\
\mathrm{~m} / \mathrm{s}\end{array}$ & $-6.8 \mathrm{~mm} / \mathrm{d}$ & $\begin{array}{l}\text { ST: }-520 \\
\mathrm{~m}^{2} / \mathrm{s} \\
\mathrm{CCV} \\
\text { satellites: - } \\
1220 \mathrm{~m}^{3} / \mathrm{s} \\
\mathrm{CCV} \mathrm{in} \mathrm{situ:} \mathrm{-} \\
1340 \mathrm{~m}^{3} / \mathrm{s}\end{array}$ \\
\hline
\end{tabular}

684 Table 3: Summary of the main modifications of five ECVs analyzed, as observed in the SCS

685 during El Niño events and on basin-averaged long-term trends during the reported years.

686 Interestingly, it has been found that each ECV responds to specific ENSO types in 687 different ways. The first EOF mode on SST (75\% of the variance) revealed that Eastern 688 Pacific El Niño types trigger a basin-wide warming of the SST with a 6-month lag. The second 689 EOF mode on SST indicated a clear correlation with all types of ENSO events (represented by 690 the SST Niño4 index). The first EOF mode on SLA (48\% of the variance) showed that the SLA 691 falls throughout the basin during an El Niño event, with a 3-month lag, and more intensely in the eastern part of SCS. Unexpectedly, the SST and SLA thus have an inverse response to ENSO. This was examined by Rong et al. (2007). Using the subsurface temperature analysis from Ishii et al. (2006), they show the coexistence of positive temperature anomalies in the upper $75 \mathrm{~m}$ (hence $>0$ SST anomalies) and negative temperature anomalies below $75 \mathrm{~m}$ (at 
Ocean Sci. Discuss., https://doi.org/10.5194/os-2017-104

Manuscript under review for journal Ocean Sci.

Discussion started: 2 January 2018

(c) Author(s) 2018. CC BY 4.0 License.

$69775 \mathrm{~m}$ versus $75-700 \mathrm{~m}$ ) result in negative anomalies of the thermosteric sea level

698 component, which account for most of the negative SLA during El Niño events.

699 Previous studies have identified different potential hypotheses to explain the 700 anomalous ENSO-related SST changes. Wang et al. (2000) attributed the SCS warming to an

701 anomalous lower-tropospheric anti-cyclonic circulation located in the western North Pacific

702 through an 'atmospheric bridge'. The anomalies can persist until the following summer. Qu

703 et al. (2004) examined the heat transport through the Luzon Strait from the Pacific into the

704 SCS and suggested that this 'oceanic bridge' between the two basins was a key process in

705 conveying the impact of the Pacific ENSO into the SCS (both for SST and SLA). The respective

706 parts of the atmospheric and oceanic bridges clearly remain to be clarified.

707 The first EOF mode (64\% of the total variance) of the zonal wind component revealed 708 that the wind increased eastwards north of $14^{\circ} \mathrm{N}$ (decreased south of $14^{\circ} \mathrm{N}$ ) during an El 709 Niño event, with a 5-month lag. The first EOF mode (49\% of the variance) of the meridional 710 wind component showed a strengthening of the northward winds north of $6^{\circ} \mathrm{N}$ (weakening 711 south of $6^{\circ} \mathrm{N}$ ) during an El Niño event, with a 3-month lag. When superimposed on the strong 712 mean seasonal cycle, the El Niño events hence produce a slowdown of the winter NE and 713 summer SW monsoon winds. For precipitation, the first EOF mode (48\% of the variance) 714 showed a decrease in rainfall over the entire region during El Niño phases. The linkage of 715 near-coastal in situ P stations and ENSO appeared to be stronger at lower latitudes in 716 Vietnam, for instance with $\mathrm{P}$ decreasing by up to $70 \%$ relative to the mean at the Da Nang 717 station during El Niño phases. Finally, water discharges taken from the Red River (at least at 718 the ST station) before the impoundment of the Hoa Binh Dam showed correlation to ENSO 719 but the post-dam impoundment period did not show a clear correlation to ENSO. The water 720 discharge from the Mekong River (at least at the CCV station) seems to respond to ENSO via 721 reduced water flow (34\% of the mean for the 1997-98 El Niño event) with a 7 to 8-month lag. 

to determine the long-term variability of the ECVs. SST has risen by $0.24^{\circ} \mathrm{C} / \mathrm{decade}$ basinwide (except along the coastlines of China and central Vietnam). The SLA increased with a mean rising rate of $4.1 \mathrm{~mm} / \mathrm{yr}$ with the highest rates in the central and the eastern parts of the SCS basin, which is approximately 3 times faster than the global rate of sea level rise. This corroborates the need to include data from the SCS (and semi-enclosed basins in general) to improve the computation of global mean sea level trends (Dieng et al., 2015). The zonal wind decreased over the period $1970-2015$ by up to $0.48 \mathrm{~m} / \mathrm{s} /$ decade in the eastern and western parts of the region. The meridional wind strengthened southwards over the entire region, except in the eastern part of the basin where the northward winds increased by up to $0.18 \mathrm{~m} / \mathrm{s} /$ decade. The satellite-derived precipitation decreased over the period (1979-2015) by approximately $0.7 \mathrm{~mm} / \mathrm{d} / \mathrm{yr}$ over almost the entire region. In situ nearcoastal P stations in Vietnam showed increasing trends at lower latitudes, while the northern stations showed slightly increasing to decreasing trends. All of the water discharges that were observed showed small relative decreasing trends with higher rates (compare to the mean) at the Red River ST station (1.5\% of the mean), which is located a few kilometers upstream of the city of Hanoi.

As a cautionary note, as discussed in England et al. (2014) and others, it is crucial to consider the likely role of the PDO in the calculations of long-term trends. An inversion of the

742 sign of the PDO (e.g., in 2000) can induce a strengthening of the Pacific trade winds, leading to the slowdown of the Pacific Ocean surface warming that has been observable since 2001 and is related to the changes in the regionally analyzed ECVs. Furthermore, as discussed in

745 the previous section and as addressed by Solomon and Newman (2012), it is essential to

746 consider the modulation of long-term trends that is induced by ENSO events (even when

747 estimated over 30 years), especially in the Indo-Pacific region. 

to be relevant to each ECV. To confirm these results, it would however be fair to analyze complementary data sets such as NCEP (Kalnay et al., 1996) and JRA-55 (Kobayashi et al., 2015) for $P$, and TropFlux (Kumar et al., 2013) for $P$, SST and surface wind. Furthermore, the growing literature that is available on the subject, and particularly the literature mentioned throughout the text, has enabled us to identify mechanisms that likely account for the observed variability at different time scales. Strictly quantifying the (common or not) mechanisms responsible for the observed anomalies (including the ones of the 2015-16 El Niño not discussed here) and trends highlighted in this paper by using outputs from ocean/atmosphere dynamic models validated with our observations seems crucial to better understand the seasonal, interannual and long-term variability of the region. This will be the subject of another study.

\section{Acknowledgments:}

762 We benefited from the freely available datasets for SST ( $\underline{\mathrm{ftp}}$ ://eclipse.ncdc.noaa.gov/pub/OIdaily-v2/), SLA (http://www.aviso/altimetry.fr/en/data/products/sea-surface-heightproducts/global/msla-mean-climatology), P (http://www.ecmwf.int/en/research/climatereanalysis/era-interim) and WD (http://ctoh.legos.obs-mip.fr). We warmly thank Vietnam's Hydro-Meteorological Service for providing the inland precipitation measurements and the Mekong River Commission for providing water discharge data from the gauge stations in Cambodia. We are also very thankful for having had the opportunity to use the Mean Dynamical Topography data provided by AVISO. Fruitful discussions with Gael Alory, Sylvain

770 Biancamaria, Frédéric Frappart, and Sylvain Ouillon, from LEGOS, help us to improve our analysis. 
Ocean Sci. Discuss., https://doi.org/10.5194/os-2017-104

Manuscript under review for journal Ocean Sci.

Discussion started: 2 January 2018

\section{References}

774

775

776

777

778

779

780

781

782

783

784

785

786

787

788

789

790

791

792

793

794

795

796

797

798

799

800

801

802

803

804

805

806

807

Allan R., Lindsay J., Parker D. (1996), El Niño Southern Oscillation and climate variability. CSIRO Publising, 150 0xford St. (PO Box 1139), Collingwood, Victoria 2066, Australia.

Camargo S. J., Sobel A. H. (2005) Western North Pacific Tropical Cyclone Intensity and ENSO. Amer. Meteor. Soc., 18: 2996-3006., doi:10.1175/JCLI3457.1.

Casey K. S., Cornillon P. (2001), Global and regional sea surface temperature trends. J. Climate. 14:3801-3818., doi: http://dx.doi.org/10.1175/15200442(2001)014<3801:GARSST>2.0.CO;2.

Cazenave A., Nerem R. S. (2004), Present-day sea level change: Observations and causes. Rev Geophys., 42: RG3001, doi: 10.1029/2003RG00139.

Cheng X., Xie S.-P., Du Y., Wang J., Chen X., Wang J. (2016), Interannual-to-decadal variability and trends of sea level in the South China Sea. Clim. Dyn., 46:3113-3126, doi: 10.1007/s00382-015-2756-1.

Chiodi A. M., Harrison A. E. (2010) Characterizing warm-ENSO variability in the equatorial Pacific: An OLR-perspective. J. Climate., 23: 2428-2439, doi: 10.1175/2009JCLI3030.1.

Chiodi A. M., Harrison A. E. (2013) El Niño impacts on seasonal U.S. atmospheric circulation, temperature, and precipitation anomalies: The ORL-event perspective. J. Climate., 26: 822-837., doi: 10.1175/JCLI-D-12-00097.1.

Chu C., Lu S., Chen Y. (1997), Temporal and spatial variabilities of the South China Sea surface temperature anomaly. J. Geophy Res., 102 (C9): 20937-20955, doi: 10.1029/97JC00982.

Dee D. P. et al., (2011) The ERA-Interim reanalysis: Configuration and performance of the data assimilation system. Q. J. Roy. Meteor. Soc., 137(656), 553-597, doi:10.1002/qj.828.

Deser C., Phillips A. S., Alexander M. A. (2010), Twentieth century tropical sea surface temperature trends revisited. Geophy. Res Lett., 37 (10): L10701, doi: 10.1029/2010GL043321.

Dieng, H. B., Cazenave, A., von Schuckmann, K., Ablain, M., and Meyssignac, B. (2015), Sea level budget over 2005-2013: missing contributions and data errors. Ocean Sci. 11, 789-802.

Dieng, H. B., Cazenave, A., Meyssignac, B., and M. Albain (2017) New estimate of sea level rise from a sea level budget approach. Geophys. Res. Lett., 44, 3744-3751, doi:10.1002/2017GL073308.. 
Ocean Sci. Discuss., https://doi.org/10.5194/os-2017-104

Manuscript under review for journal Ocean Sci.

Discussion started: 2 January 2018

808

809

810

811

812

813

814

815

816

817

818

819

820

821

822

823

824

825

826

827

828

829

830

831

832

833

834

835

836

837

838

839

840

841

842

England, M., S. McGregor, P. Spence, G. A. Meehl, A. Timmermann, W. Cai, A. S. Gupta, M. J. McPhaden, A. Purich, and A. Santoso (2014), Recent intensification of wind-driven circulation in the Pacific and the ongoing warming hiatus, Nat. Clim. Change, 4, 222227, doi:10.1038/nclimate210.

Fang G, Chen H, Wei Z, Wang Y, Wang X, Li C (2006) Trends and interannual variability of the South China Sea surface winds, surface height, and surface temperature in the recent decade. J. Geoph. Res. 111: CS11S16, doi: 10.1029/2005JC003276.

Farris A., Wimbush M. (1996) Wind-induced Kuroshio intrusion into the South China Sea. J. Oceanogr., 52, 771-784, doi: 10.1007/BF02239465.

Frappart F., Papa F., Marieu V., Malbéteau Y., Jordy F., Calmant S., Durand F., Bala S. (2015) Preliminary assessment of SARAL/AltiKa observations over the GrangesBrahmaputra and Irrawaddy Rivers. Mar. Geod. 38(S1): 568-580, doi: 10.1080/01490419.2014.990591

Frappart F., Legrésy B., Niño F., Blare F., Fuller N., Fleury S., Birol F., Calmant S. (2016) An ERS-2 altimetry reprocessing compatible with ENVISAT for long-term land and ice sheets studies. Remote Sens. Environ. 184: 558-581, doi: 10.1016/j.rse.2016.07.037.

GCOS (2016). The Global Climate Observing System: implementation needs, GCOS-200, GOOS-214. World Meteorological Organization, 325 pages (Available at: http://unfccc.int/files/science/workstreams/systematic observation/application/pd f/gcos ip 10oct2016.pdf)

Gobin A., Nguyen H. T., Pham V. Q., Pham H. T. T. (2016) Heavy rainfall patterns in Vietnam and their relation with ENSO cycles. Int. J. Climatol. 36: 1686-1699, doi: 10.1002/joc.4451.

Hanley D. E., Bourassa M. A., O’Brien J. J., Smith S. R., Spade E. R. (2003) A quantitative evaluation of ENSO indices. J. Climate, 16: 1249-1258, doi: http://dx.doi.org/10.1175/1520-0442(2003)16<1249:AQEOIEI>2.0.CO

Hannachi A., Jolliffe I. T., Stephenson D. B. (2007) Empirical orthogonal functions and related techniques in atmospheric sciences: A review. Int. J. Climatol., 27, 1119-1152, doi: 10.1002/joc.1499.

Ho C.-R., Zheng Q., Soong Y. S., Kuo N.-J., Hu J.-H. (2000) Seasonal variability of sea surface height in the South China Sea observed with TOPEX/Poseidon altimeter data. J. Geophys. Res. 105: 13981-13990, doi: 10.1029/2000JC900001.

Huynh H.-N., Alvera-Azcarate A., Barth A., Beckers J.-M. (2016), Reconstruction and analysis of long-term satellite-derived sea surface temperature for the South China Sea. J. Oceanogr., 1-20, doi: 10.1007/s10872-016-0365-1. 
Ocean Sci. Discuss., https://doi.org/10.5194/os-2017-104

Manuscript under review for journal Ocean Sci.

Discussion started: 2 January 2018

843

844

845

846

847

848

849

850

851

852

853

854

855

856

857

858

859

860

861

862

863

864

865

866

867

868

869

870

871

872

873

874

875

876

877

IPCC Fourth Assessment Report (AR4): Contribution of Working Group I, II and III to the Fourth Assessment Report of the Intergovernmental Panel on Climate Change. Core Writing Team, Pachauri R. K. And, Reisinger A. (Eds), IPCC, Geneva, Switzerland. Pp 104.

Ishii, M., Kimoto, M., Sakamoto, S., Iwasaki, S.-I. (2006) Steric sea level changes estimated from historical ocean subsurface temperature and salinity analyses. J. Oveanogr., 62 (2), 155-170.

Juneng L., Tangang F. T. (2005), Evolution of ENSO-related rainfall anomalies in Southeast Asia region and its relationship with atmosphere-ocean variations in Indo-Pacific sector. Clim. Dynam., 25: 337-350, doi: 10.1007/s00382-005-0031-6.

Kalnay E, et al. (1996) The NCEP/NCAR 40-year reanalysis project. Bulletin of American Meteorology Society, 77(3), 437-471, doi: https://doi.org/10.1175/15200477(1996)077<0437:TNYRP>2.0.C0;2.

Klein S. A., Soden B. J., Lau N.-C. (1999), Remote sea surface temperature variations during ENSO: Evidence for a tropical atmospheric bridge. J. Climate, 12, 917-932, doi: http://dx.doi.org/10.1175/1520-0442(1999)012<0917:RSSTVD>2.0.CO;2.

Kobayashi S, et al. (2015) The JRA-55 Reanalysis: General specifications and basic characteristics. Journal of the Meteorological Society of Japan, 93, 5-,48, doi: http://doi.org/10.2151/jmsj.2015-001.

Kouraev A. V., Zakharova E. A., Samain O., Mognard N. M., Cazenave A. (2004), Ob's river discharge from TOPEX/Poseidon satellite altimetry (1992-2002). Remote Sens. Environ., 93, 238-245, doi: http://doi.dx.org/10.1016/j.rse.2004.07.007.

Kumar Praveen B., Vialard J., Lengaigne M., Murty V. S. N., McPhaden M.J. (2012) TropFlux: air-sea fluxes for the global tropical oceans - description and evalution. Clim. Dyn. 38, 1521, doi:10.1007/s00382-011-1115-0.

Leuliette E. W., Willis J. K. (2011), Balancing the sea level budget. Oceanography. 24(2):122129., doi:10.5670/oceanog.2011.32

Liu Q., Jiang X., Xie S.-P., Liu W. T. (2004) A gap in the Indo-Pacific warm pool over the South china Sea in borel winter: Seasonal development and interannual variability. J. Geophys. Res., 109(C07012), doi:10.1029/2003JC002179.

Lu X.X, Siew R.Y. (2006), Water discharge and sediment flux changes over the past decades in the Lower Mekong River: possible impact of the Chinese dams. Hydrol. Earth. Syst. Sci., 10: 181-195, doi: hal-00304834.

Manton M. J., Della-Marta P. M., Haylock M. R., Hennessy K. J., Nicholls N., Chambers L. E., Collins D. A., Daw G., Finet A., Gunawan D., Inape K., Isobe H., Kestin T. S., Lefale P., 
878

879

880

881

882

883

884

885

886

887

888

889

890

891

892

893

894

895

896

897

898

899

900

901

902

903

904

905

906

907

908

909

910

911

Leyu C. H., Lwin T., Maitrepierre L., Ouprasitwong N., Page C. M., Pahalad J., Plummer N., Salinger M. J., Suppiah R., Tran V. L., Trewin B., Tibig I., Yee D. (2001), Int J Climatol., 21:269-284, doi: 10.1002/joc.610.

Mantua N. J., Hare S. R. (2002), The Pacific Decadal Oscillation. J. Oceanogr.. 58(1), 35-44.

Mei W., Xie S.-P. (2016), Intensification of the landfalling typhoons over the northwest Pacific since the late 1970s. Nat. Geosci., 9: 753-758, doi:10.1038/NGE02792.

Meyssignac B., Llovel W., Cazenave A., Salas-Melia D., Becker M. (2012) Tropical Pacific spatial trend patterns in observed sea level: internal variability and/or anthropogenic signature? Climate of the Past. 8:787-802. doi: 10.5194/cp-8-787-2012

Nguyen D.-Q., Renwick J., McGregor J. (2014), Variations of surface temperature and rainfall in Vietnam from 1971 to 2010. Int. J Climatol., 34, 249-264, doi: 10.1002/joc.3684.

North G. R., Bell T. L., Cahalan R. F., Moeng F. J. (1982), Sampling Errors in the Estimation of Empirical Orthogonal Functions. Amer. Meteor. Soc., 110: 699-706, doi: http://dx.doi.org/10.1175/1520-0493(1982)110<0699:SEITEO>1.0.CO;2.

Peng D., Palanisamy H., Cazenave A., Meyssignac B. (2013), Interannual Sea Level Variations in the South China Sea over 1950-2009. Mar. Geod., 36: 164-182, doi: http://dx.doi.org/10.1080/01490419.2013.771595.

Qu T. (2001) Role of the ocean dynamics in determining the mean seasonal cycle of the South China Sea surface temperature. J Geophys. Res., 106: 6943-6955, doi: 10.1029/2000JC000479.

Qu T., Kim Y. Y., Yaremchuk M., Tozuka T., Ishida A., Yamagata T. (2004) Can Luzon Strait Transport play a role in conveying the impact of ENSO to the South China Sea? J. Climate, 17: 3644-3657, doi: https://doi.org/10.1175/15200442(2004)017<3644:CLSTPA>2.0.C0;2.

Qu T., Song T., Yamagata T. (2009) An introduction to the South China Sea throughflow : its dynamics, variability and application for climate. Dyn. Atmosph. Oceans, 47, 3-,14.

Räsänen T. A., Kummu M. (2013), Spatiotemporal influences of ENSO on precipitation and flood pulse in the Mekong River Basin. J of Hydrol., 476, 154-168, doi: http://dx.doi.org/10.1016/j.hydrol.2012.10.028.

Räsänen T. A., Lindgren V., Guillaume J. H. A., Buckley B. M., Kummu M. (2016) On the spatial and temporal variability of ENSO precipitation and drought teleconnection in mailand Southeast Asia. Clim. Past., 12, 1889-1905, doi: 10.5194/cp-12-1889-2016..

Rayner N. A., Parker D. E., Horton E. B., Folland C. K., Alexander L. V., Rowell D. P., Kent E. C., Kaplan A. (2003), Global analysis of sea surface temperature, sea ice, and night 
Ocean Sci. Discuss., https://doi.org/10.5194/os-2017-104

Manuscript under review for journal Ocean Sci.

Discussion started: 2 January 2018

912

marine air temperature since the late nineteeth century. J. Geophys. Res., 108(D14): 4407, doi: 10.1029/2002JD002670.

Reynolds R. W., Smith T. M., Liu C., Chelton D. B., Casey K. S., Schlax M. G. (2007) Daily HighResolution-Blended Analyses for Sea Surface Temperature. American Meteorological Society. 20: 5473, 5496, doi: http://dx.doi.org/10.1175/2007/JCLI1824.1.

Rio M.-H., Mulet S., Picot N. (2014), Beyond GOCE for the ocean circulation estimate: Synergetic use of altimetry, gravimetry, and in situ data provides new insight into geostrophic and Ekman currents. Geophys. Res. Lett., 41: 8918-8925, doi: 10.1002/2014GL061773.

Rong Z., Liu Y., Zong H., Cheng Y. (2007), Interannual sea level variability in the South China Sea and its response to ENSO. Global Planet. Change, 55, 257-272, doi: http://dx.doi.org/10.1016/j.gloplacha.2006.08.001.

Saji N. H., Goswami B. N., Vinayachandran P. N., Yamagata T. (1999), A, dipole mode in the tropical Indian Ocean. Nature, 401: 360-363.

Sing A., Delcroix T., Cravatte A. (2011) Contrasting the flavors of El Niño Southern Oscillation using sea surface salinity observations. J. Geophys. Res., 116: C06016, doi:10.1029/2010JC006862.

Solomon A., Newman M. (2012), Reconciling disparate twentieth-century Indo-Pacific ocean temperature trends in the instrumental record. Nat. Clim. Change., 2: 691-697, doi: 10.1038/nclimate1591.

Tan W., Wang X., Wang W., Wang C., Zuo J. (2016) Different Responses of Sea Surface Temperature in the South China Sea to Various El Niño Events during Boreal Autumn. J. Climate., 29, 1127-1142, doi: http://dx.doi.org/10.1175/JCLI-D-15-0338.1.

Trenberth K. E., Hoar T. J. (1997) El Niño and climate change. Geophys. Res. Lett. 24: 30573060, doi: 10.1020/97GL03092.

Trenberth K. E., Stepaniak D. P. (2001) Indices of El Niño Evolution. J. Climate., 14 : 1697 1701., doi: http://dx.doi.org/10.1175/15200442(2001)014<1697:LIOENO>2.0.CO;2.

Tuen K. L. (1994) Monitoring of sea surface temperature in the South China Sea. Hydrobiologia. 285: 1-5, doi: 10.1007/978-94-011-0958-1_1.

Vinh V. D., Ouillon S., Thanh T. D., Chu L. V. (2014), Impact of the Hoa Binh dam (Vietnam) on water and sediment budgets in the Red River basin and delta. Hydrolg. Earth Sci., 18: 3987-4005, doi: 10.5194/hess-18-3987-2014. 
Ocean Sci. Discuss., https://doi.org/10.5194/os-2017-104

Manuscript under review for journal Ocean Sci.

Discussion started: 2 January 2018

(C) Author(s) 2018. CC BY 4.0 License.

Discussions

(c) $\underset{\mathrm{BY}}{\mathrm{P}}$

945

946

947

948

949

950

951

952

953

954

955

956

957

958

959

960

961

962

963

964

965

966

967

968

969

970

971

972

973
Wang B., LinHo (2002), Rainy season of the Asian-Pacific summer monsoon. J. Climate., 15, 386-398, doi: http://dx.doi.org/10.1175/15200442(2002)015<0383:RSOTAP>2.0.CO;2.

Wang B., H, uang F., Wu Z., Yang J., Fu X., Kikuchi K. (2009) Multi-scale climate variability of the South China Sea monsoon: A review. Dyn. Atmosph. Oceans, 47, 3-,14

Wang B., Wu R., Fu X. (2000) Pacific-East Asian Teleconnection: How does ENSO affect East Asian climate? J. Climate, 13: 1517-1536, doi: https://doi.org/10.1175/15200442(2000)013<1517:PEATHD>2.0.CO;2

Wang C., Wang W., Wang D., Wang Q. (2006), Interannual variability of the South China Sea associated with El Niño. J. Geophys. Res., 111: C03023, doi: 10.1029/2005JC003333.

Wang C., Xie S.-P., Carton J. A. (2004) A global survey of ocean-atmosphere interaction and climate variability, in Earth Climate: The Ocean-Atmosphere Interaction edited by Wang C et al., 1-19, AGU, Washington D C.

Wyrtki, K., 1961: Physical oceanography of the Southeast Asian waters. Naga Rep. 2, 195 pp. [Available from: https://escholarship.org/uc/item/49n9x3t4].

Wu C.-H., June Chang C.-W. (2005) Interannual variability of the South China Sea in a data assimilation model. J. Geophys. Res., 32:LI7611, doi:10.1029/2005GL023798

Wu L., Wang B., Geng S. (2005) Growing typhoon influence on east Asia. Geophys. Res. Lett., 32 (18), LI8703, doi:10.1029/2005GL022937.

Yang Y., XIe S.-P., Du Y., Tokinaga H. (2015) Interdecadal difference of interannual variability characteristics of South China Sea SSTs associated with ENSO. Amer Mereor Soc. 28: 7145-7160, doi:10.1175/JCLI-D-15-0057.1

Xue Z., Liu J. P., Ge Q. (2011) Changes in hydrology and sediment delivery of the Mekong River in the last 50 years: connection to damming, monsoon, and ENSO. Earth Surf. Proc. Land., 36: 296-308, doi: 10.1002/esp.2036.

Zhuang W., Xie S.-P., Wang D., Taguchi B., Aiki H., Sasaki H. (2010) Intraseasonal variability in sea surface height over the South China Sea. J. Geophys. Res., 115: C04010, doi:10.1029/2009JC005647. 